\title{
Bivalve Diversity on the Continental Shelf and Deep Sea of the Perdido Fold Belt, Northwest Gulf of Mexico, Mexico
}

\author{
Nancy Yolimar Suárez-Mozo ${ }^{1,2} \mathbb{D}$, Victor Manuel Vidal-Martínez ${ }^{3} \mathbb{D}$, M. Leopoldina Aguirre-Macedo ${ }^{3}(\mathbb{D}$, \\ Daniel Pech 4 (D), Edlin Guerra-Castro ${ }^{5,6}$ (D) and Nuno Simões $2,6,7, *$ (D)
}

1 Posgrado en Ciencias del Mar y Limnología, Universidad Nacional Autónoma de México, Av. Ciudad Universitaria 3000, Coyoacán, Ciudad de México C.P. 04510, Mexico; nancyyolimarbio@gmail.com

2 Unidad Multidisciplinaria de Docencia e Investigación Sisal (UMDI-SISAL), Facultad de Ciencias, Universidad Nacional Autónoma de México, Puerto de abrigo s/n, Sisal, Yucatán C.P. 97356, Mexico

3 Centro de Investigación y de Estudios Avanzados del IPN Unidad Mérida, Departamento de Recursos del Mar, Carretera Antigua a Progreso km 6, Mérida, Yucatán C.P. 97310, Mexico; vvidal@cinvestav.mx (V.M.V.-M.); leopoldina.aguirre@cinvestav.mx (M.L.A.-M.)

4 Laboratorio de Biodiversidad Marina y Cambio Climático, El Colegio de la Frontera Sur, Av. Rancho Polígono 2-A, Col. Ciudad Industrial, Lerma, Campeche C.P. 24500, Mexico; dpech@ecosur.mx

5 Escuela Nacional de Estudios Superiores, Unidad Mérida, Universidad Nacional Autónoma de México, Carretera Mérida-Tetiz, Km 4, Ucú, Yucatán C.P. 97357, Mexico; edlin.guerra@enesmerida.unam.mx

6 Laboratorio Nacional de Resiliencia Costera, Laboratorios Nacionales, CONACYT, Mexico City 03940, Mexico

7 International Chair for Coastal and Marine Studies, Harte Research Institute for Gulf of Mexico Studies, Texas A and M University-Corpus Christi, Corpus Christi, TX 77843, USA

* Correspondence: ns@ciencias.unam.mx

check for updates

Citation: Suárez-Mozo, N.Y.; Vidal-Martínez, V.M.;

Aguirre-Macedo, M.L.; Pech, D.; Guerra-Castro, E.; Simões, N. Bivalve Diversity on the Continental Shelf and Deep Sea of the Perdido Fold Belt, Northwest Gulf of Mexico, Mexico. Diversity 2021, 13, 166. https://doi.org/10.3390/d13040166

Academic Editor: Saskia Brix

Received: 8 March 2021

Accepted: 7 April 2021

Published: 12 April 2021

Publisher's Note: MDPI stays neutral with regard to jurisdictional claims in published maps and institutional affiliations.

Copyright: (c) 2021 by the authors. Licensee MDPI, Basel, Switzerland. This article is an open access article distributed under the terms and conditions of the Creative Commons Attribution (CC BY) license (https:// creativecommons.org/licenses/by/ $4.0 /)$.

\begin{abstract}
Mollusk diversity in coastal areas of the Gulf of Mexico (GOM) has been studied extensively, but this is not the case for deep-water habitats. We present the first quantitative characterization of mollusks in shallow and deep waters of the Perdido Fold Belt. The data came from two research cruises completed in 2017. Sediment samples were collected from 56 sites using a $0.25-\mathrm{m}^{2}$ box corer. We tested hypotheses about spatial patterns of $\alpha, \beta$, and $\gamma$-diversity of bivalves in two water-depth zones, the continental shelf $(43-200 \mathrm{~m})$ and bathyal zone $(375-3563 \mathrm{~m})$. A total of 301 bivalves belonging to 39 species were identified. The two zones display similar levels of $\gamma$-diversity, but host different bivalve assemblages. In general, $\alpha$-diversity was higher on the continental shelf, whereas $\beta$-diversity was higher in the bathyal zone. These patterns can be explained by the higher input of carbon (energy) to the near-coast shelf zone, as well as by the greater topographic complexity of habitats in the bathyal zone. These results enabled us to propose redirection of sampling efforts for environmental characterization from continental zones to the deep-water zone, especially in the context of environmental assessments during oil and gas exploration and production.
\end{abstract}

Keywords: bivalves; deep-sea fauna; species diversity; shelf and bathyal habitats; Gulf of Mexico

\section{Introduction}

The deep sea extends beyond the depth of the photic zone and the edge of the continental shelf, which lies at about $200 \mathrm{~m}$ depth [1,2]. Nomenclature for bathymetric zones in the deep sea is not consistent and can differ depending on the taxonomic group being studied. Although there is some disagreement regarding the terminology applied to these marine zones and their bathymetric limits, we follow the system proposed by [3]. The perception that deep-sea communities are "desert-like" and display low taxonomic diversity has changed in the last few decades [4]. It is now known that these deep-water environments are rich in species, comparable to coastal marine habitats [2,5-7], and that the deep sea is highly complex and governed by interactions among multiple environmental factors [8,9]. Only a small proportion of deep-sea realm, however, has been studied, because its exploration is technically difficult and expensive [10,11]. 
Mollusks are routinely used for marine biodiversity assessment [12-19] and to explore diversity patterns across broad latitudinal and bathymetric gradients [12,20]. This is because: (1) Mollusca is one of the most common species of the marine animal phyla, (2) they possess durable shells, and (3) they are abundant. Shells can, thus, be collected without risk of damage, providing an opportunity to compare modern spatial patterns of biodiversity with those of past communities [21]. One conclusion that has emerged from sampling studies [22] is that assemblages of living mollusks are in fact rare, and most individuals collected during sampling represent the remains of dead organisms (i.e., death assemblages). This makes it difficult to evaluate modern biodiversity metrics, which can be overestimated if the relation between live and dead community variables is not analyzed [21,23]. In general, fidelity of death assemblages to local living assemblages is strongly affected by human disturbances [24], especially on narrow shelves, $\leq 50 \mathrm{~km}$ from shore to the 200-m isobath. Beyond that limit, death assemblages can be used to identify recent ecological shifts in benthic communities, caused by natural phenomena and anthropogenic perturbations, if the strength of the taphonomic inertia was measured [24,25].

Development of marine mollusk inventories has contributed to knowledge about the bivalve fauna and its geographic and bathymetric distributions. The mollusk database for the Gulf of Mexico (GOM) does not distinguish between animals collected alive or dead, but can be used to investigate species richness and trophic diversity, as well as biogeographic and bathymetric distribution patterns [26]. In other regions, although death assemblages of bivalve shells do not provide information about temporal changes in the community, they do provide useful data on diversity [27]. Taxonomic determination for many species is still unresolved, as many taxa are known only from their shells [28]. Nevertheless, shells retain information about larval strategies, which can be used to understanding dispersal mechanisms [28]. Additionally, in unexplored regions such as the Mexican part of the Perdido Fold Belt (PFB), mollusk shells provide baseline data on the distribution of bivalve species under "normal circumstances", and thus, yield information about the environmental variability within the ecosystem.

Because of interest in oil exploration and recent accidents such as the Deepwater Horizon spill, some deep-sea habitats in the GOM have been sampled extensively and intensively, especially areas in the northern GOM $[29,30]$. In recent years, the Mexican part of the deep-water Perdido Fold Belt (PFB), close to coastal zone of Tamaulipas (Figure 1), has become an area of great interest because of its potentially important oil and gas reserves [31,32]. The prospect of future commercial exploitation of the region should spur interest in conducting research on deep-water marine biodiversity in the GOM.

Inventories of deep-sea fauna in the GOM have been carried out largely in U.S. territorial waters [33-37], and to a lesser extent at sites elsewhere in the GOM [38,39]. One pattern suggested by previous studies is that the density and diversity of bivalve species on the sediment surface decreases gradually from the continental, shallow-water sites to the deepest localities, possibly because of the relatively greater complexity of geophysical variables and nutrient availability in shallower waters [33]. There are, however, no quantitative estimates of differences in species diversity between the deep- and shallowwater habitats of the PFB. Such information is particularly important in the context of deep-water environmental assessments, but especially for understanding the diversity of one of the oldest and most biodiverse animal groups.

Given the traditional perceptions about differences in shallow- and deep-water marine environments, and the lack of knowledge about the diversity of bivalve mollusk in deepwater habitats of the Mexican part of the PFB, this study had two objectives: (1) to document the bivalve mollusk species in the PFB; and (2) to assess spatial patterns of diversity ( $\alpha, \beta$ and $\gamma$ ) of bivalve mollusks in the PFB region, with respect to water depth, specifically from the continental shelf to the bathyal zone. 


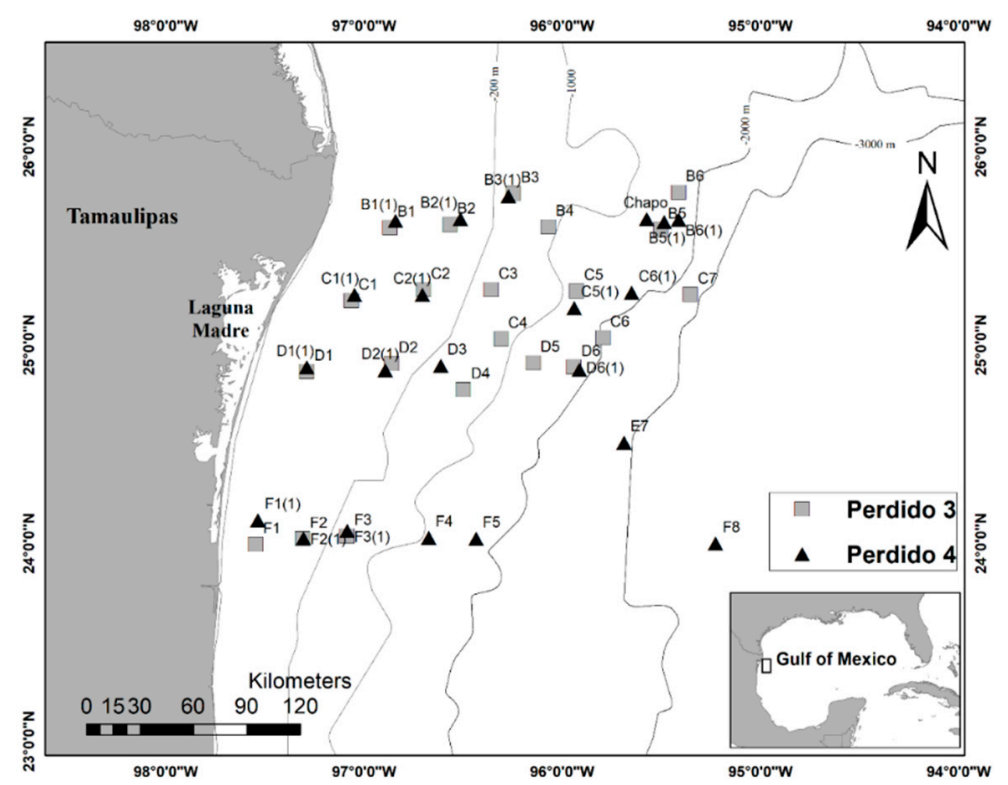

Figure 1. Mollusk sampling sites on Perdido Fold Belt during the Perdido 3 cruise (squares symbol) and Perdido 4 cruise (triangles symbol), in June and September 2017, respectively. Samples were assigned to two water-depth zones: the continental shelf (43-200 m) and bathyal zone (375-3563 m), separated by the $200 \mathrm{~m}$ isobath. Acronym: Chapo = oil seep.

\section{Materials and Methods}

The study area included the southern Perdido Fold Belt, a section of the Tamaulipas shelf, and the Rio Bravo slope [40]. The PFB is a frontier petroleum exploration province in the GOM, located off the east coast of Mexico [41], with an area of $\sim 272,300 \mathrm{~km}^{2}$ [10] and water depths between 2000 and $3600 \mathrm{~m}$ [42,43] (Figure 1). The northern sector has been well studied with geophysical surveys [32], whereas the southerly sector, in Mexican waters, is poorly known [32]. The PFB is part of the allochthonous salt sheets of the Sigsbee salt nappe [33]. Sediment input comes from the Hudson and Rio Grande embayments, located to the north and west, respectively [32,44,45].

\subsection{Sample Collection}

Bivalve comprise part of the benthic macrofauna and their shells, along with some live animals, were collected from soft-bottom sediments at water depths between 43 and $3563 \mathrm{~m}$, and assigned to two water-depth zones: (1) the continental shelf samples (43-200 m) and (2) bathyal zone (375-3563 m) (Figure 1, Table 1). Samples were collected from the Research Vessel "Justo Sierra" (Universidad Nacional Autónoma de Mexico) during oceanographic cruises Perdido 3 in June 2017 (29 sites), and Perdido 4 in September 2017 (27 sites) (Table 1). At each sampling site, sediment was collected using a $0.25-\mathrm{m}^{2}$ Hessler Sandia MK-III box corer. Site, latitude, longitude, water depth, zone, and cruise information for each sample were recorded (Table 1). Each sediment sample was subsampled for: bacteria, chemical contaminants, metals, sediment texture, and benthic fauna community (three subsamples). Subsequently, sediment samples were sieved through 500- and 300- $\mu \mathrm{m}$ mesh sizes. Retained shells were placed in labeled plastic bags and examined later in the laboratory.

Shells were identified to species level, following standard guides [38,46-49]. For each species or morphotype, it was noted whether the individual was alive (soft part intact) or dead (empty shell), and the degree of shell damage was evaluated to assess whether the shell had been subject to post-mortem transport. Shell damage can also be used as a surrogate measure for time of death. We assumed that a well-preserved shell (i.e., no signs of abrasion or fractures) indicated that the organism had lived in the area recently. Worn and broken shells suggested transport from elsewhere, or that the organism may have lived 
in the area, but died long ago. We compared the observed assemblages with an exhaustive inventory of Bivalvia species from the GOM that had information on depth range and habitat preferences [39]. The list, however, did not distinguish between provenance of live and dead shells in the records, and provided only general location data for species presence/absence information, without specific geographic coordinates, thus precluding site-specific comparisons. Nomenclature for our sampled species was assigned according to [50] and The World Register of Marine Species (WoRMS) [51]. Specimens were deposited in the collection "Moluscos de la Peninsula de Yucatán" (CMPY), UMDI-Sisal, UNAM, Yucatan, Mexico and in the collection of the laboratory "Biodiversidad Marina y Cambio Climático "BIOMARCCA", ECOSUR-Campeche, Mexico.

Table 1. Sampling locations where bivalves were collected in the Perdido Fold Belt, Gulf of Mexico.

\begin{tabular}{|c|c|c|c|c|c|c|}
\hline Site & $\begin{array}{c}\text { Date } \\
(\mathrm{d} / \mathrm{m} / \mathrm{yr})\end{array}$ & Latitude $\left({ }^{\circ} \mathbf{N}\right)$ & $\begin{array}{c}\text { Longitude } \\
\left({ }^{\circ} \mathrm{W}\right)\end{array}$ & Depth (m) & Zonation & Cruise \\
\hline D1 & $9 / 06 / 2017$ & $24^{\circ} 51.985^{\prime}$ & $97^{\circ} 17.431^{\prime}$ & 43 & Continental shelf & Perdido 3 \\
\hline 1 & $8 / 06 / 2017$ & $23^{\circ} 59.700^{\prime}$ & $97^{\circ} 32.855^{\prime}$ & 45.8 & Continental shelf & Perdido 3 \\
\hline $\mathrm{C} 1$ & $10 / 06 / 2017$ & $25^{\circ} 13.506^{\prime}$ & $97^{\circ} 03.913^{\prime}$ & 46 & Continental shelf & Perdido 3 \\
\hline B2 & $10 / 06 / 2017$ & $25^{\circ} 36.509^{\prime}$ & $96^{\circ} 34.057^{\prime}$ & 48.8 & Continental shelf & Perdido 3 \\
\hline B1 & $10 / 06 / 2017$ & $25^{\circ} 35.57^{\prime}$ & $96^{\circ} 52.179^{\prime}$ & 49.67 & Continental shelf & Perdido 3 \\
\hline $\mathrm{F} 2$ & 8/06/2017 & $24^{\circ} 01.428^{\prime}$ & $97^{\circ} 18.686^{\prime}$ & 86.4 & Continental shelf & Perdido 3 \\
\hline $\mathrm{C} 2$ & $10 / 06 / 2017$ & $25^{\circ} 16.740^{\prime}$ & $96^{\circ} 42.041^{\prime}$ & 98 & Continental shelf & Perdido 3 \\
\hline D2 & 9/06/2017 & $24^{\circ} 54.389^{\prime}$ & $96^{\circ} 51.808^{\prime}$ & 200 & Continental shelf & Perdido 3 \\
\hline F3 & $8 / 06 / 2017$ & $24^{\circ} 2.231^{\prime}$ & $97^{\circ} 5.234^{\prime}$ & 439 & Bathyal & Perdido 3 \\
\hline C3 & $11 / 06 / 2017$ & $25^{\circ} 16.755^{\prime}$ & $96^{\circ} 21.591^{\prime}$ & 508 & Bathyal & Perdido 3 \\
\hline B3 & $11 / 06 / 2017$ & $25^{\circ} 45.939^{\prime}$ & $96^{\circ} 14.808^{\prime}$ & 514 & Bathyal & Perdido 3 \\
\hline B4 & $11 / 06 / 2017$ & $25^{\circ} 35.795^{\prime}$ & $96^{\circ} 04.25^{\prime}$ & 959.5 & Bathyal & Perdido 3 \\
\hline $\mathrm{C} 4$ & $14 / 06 / 2017$ & $25^{\circ} 01.837^{\prime}$ & $96^{\circ} 18.620^{\prime}$ & 960 & Bathyal & Perdido 3 \\
\hline D4 & $14 / 06 / 2017$ & $24^{\circ} 46.555^{\prime}$ & $96^{\circ} 30.0015^{\prime}$ & 960 & Bathyal & Perdido 3 \\
\hline D5 & $14 / 06 / 2017$ & $24^{\circ} 54.6653^{\prime}$ & $96^{\circ} 08.8178^{\prime}$ & 1244 & Bathyal & Perdido 3 \\
\hline C5 & $12 / 06 / 2017$ & $25^{\circ} 16.420^{\prime}$ & $95^{\circ} 55.737^{\prime}$ & 1371 & Bathyal & Perdido 3 \\
\hline B5 & $12 / 06 / 2017$ & $25^{\circ} 34.969^{\prime}$ & $95^{\circ} 30.273^{\prime}$ & 1500 & Bathyal & Perdido 3 \\
\hline B6 & $13 / 06 / 2017$ & $25^{\circ} 46.2554^{\prime}$ & $95^{\circ} 24.832^{\prime}$ & 1794 & Bathyal & Perdido 3 \\
\hline D6 & $13 / 06 / 2017$ & $24^{\circ} 53.411^{\prime}$ & $95^{\circ} 56.540^{\prime}$ & 1957 & Bathyal & Perdido 3 \\
\hline C6 & $12 / 06 / 2017$ & $25^{\circ} 02.269^{\prime}$ & $95^{\circ} 47.748^{\prime}$ & 2080 & Bathyal & Perdido 3 \\
\hline $\mathrm{C} 7$ & $13 / 06 / 2017$ & $25^{\circ} 15.347^{\prime}$ & $95^{\circ} 21.281^{\prime}$ & 2644 & Bathyal & Perdido 3 \\
\hline D1(1) & $20 / 09 / 2017$ & $24^{\circ} 53.313^{\prime}$ & $97^{\circ} 17.421^{\prime}$ & 43.48 & Continental shelf & Perdido 4 \\
\hline $\mathrm{C} 1(1)$ & $24 / 09 / 2017$ & $25^{\circ} 15.233^{\prime}$ & $97^{\circ} 2.974^{\prime}$ & 48.23 & Continental shelf & Perdido 4 \\
\hline $\mathrm{F} 1(1)$ & $19 / 09 / 2017$ & $24^{\circ} 6.997^{\prime}$ & $97^{\circ} 32.212^{\prime}$ & 48.7 & Continental shelf & Perdido 4 \\
\hline B1(1) & $24 / 09 / 2017$ & $25^{\circ} 37.581$ & $96^{\circ} 50.596^{\prime}$ & 51.52 & Continental shelf & Perdido 4 \\
\hline F2(1) & $20 / 09 / 2017$ & $24^{\circ} 1.479^{\prime}$ & $97^{\circ} 18.411^{\prime}$ & 93.38 & Continental shelf & Perdido 4 \\
\hline $\mathrm{B} 2(1)$ & $24 / 09 / 2017$ & $25^{\circ} 38.112^{\prime}$ & $96^{\circ} 30.958^{\prime}$ & 96 & Continental shelf & Perdido 4 \\
\hline C2(1) & $24 / 09 / 2017$ & $25^{\circ} 15.195$ & $96^{\circ} 42.419^{\prime}$ & 104 & Continental shelf & Perdido 4 \\
\hline D2(1) & $20 / 09 / 2017$ & $24^{\circ} 52.351^{\prime}$ & $96^{\circ} 53.716^{\prime}$ & 107.6 & Continental shelf & Perdido 4 \\
\hline F3(1) & $20 / 09 / 2017$ & $24^{\circ} 3.784^{\prime}$ & $97^{\circ} 5.182^{\prime}$ & 375 & Bathyal & Perdido 4 \\
\hline D3 & $21 / 09 / 2017$ & $24^{\circ} 53.778^{\prime}$ & $96^{\circ} 36.897^{\prime}$ & 379 & Bathyal & Perdido 4 \\
\hline B3(1) & $24 / 09 / 2017$ & $25^{\circ} 45.109^{\prime}$ & $96^{\circ} 16.363^{\prime}$ & 438 & Bathyal & Perdido 4 \\
\hline C5(1) & $24 / 09 / 2017$ & $25^{\circ} 11.221^{\prime}$ & $95^{\circ} 56.514^{\prime}$ & 1267 & Bathyal & Perdido 4 \\
\hline Chapo & $23 / 09 / 2017$ & $25^{\circ} 38.176^{\prime}$ & $95^{\circ} 34.583^{\prime}$ & 1315 & Bathyal & Perdido 4 \\
\hline F4 & $28 / 09 / 2017$ & $24^{\circ} 1.696^{\prime}$ & $96^{\circ} 40.524^{\prime}$ & 1378 & Bathyal & Perdido 4 \\
\hline B5(1) & $23 / 09 / 2017$ & $25^{\circ} 37.285^{\prime}$ & $95^{\circ} 29.292^{\prime}$ & 1543 & Bathyal & Perdido 4 \\
\hline C6(1) & $22 / 09 / 2017$ & $25^{\circ} 15.872^{\prime}$ & $95^{\circ} 39.099^{\prime}$ & 1660 & Bathyal & Perdido 4 \\
\hline $\mathrm{B} 6(1)$ & $23 / 09 / 2017$ & $25^{\circ} 37.969^{\prime}$ & $95^{\circ} 24.863^{\prime}$ & 1774 & Bathyal & Perdido 4 \\
\hline F5 & $27 / 09 / 2017$ & $24^{\circ} 1.427^{\prime}$ & $96^{\circ} 26.205^{\prime}$ & 1905 & Bathyal & Perdido 4 \\
\hline D6(1) & $22 / 09 / 2017$ & $24^{\circ} 52.549^{\prime}$ & $95^{\circ} 54.934^{\prime}$ & 2130 & Bathyal & Perdido 4 \\
\hline E7 & $25 / 09 / 2017$ & $24^{\circ} 30.423^{\prime}$ & $95^{\circ} 41.441^{\prime}$ & 3053 & Bathyal & Perdido 4 \\
\hline F8 & $26 / 09 / 2017$ & $23^{\circ} 59.911^{\prime}$ & $95^{\circ} 13.687^{\prime}$ & 3563 & Bathyal & Perdido 4 \\
\hline
\end{tabular}




\subsection{Data Analysis}

Spatial patterns of bivalve diversity were described using the following metrics: (1) $\alpha$-diversity, as the mean number of species per site; (2) $\beta$-diversity, as the variation in species composition among sites within the study area [52,53], and (3) $\gamma$-diversity, as the expected number of species in each zone (i.e., shelf and bathyal). Specifically, $\gamma$-diversity was estimated using two incidence-based, non-parametric estimators: Chao2 and 1storder Jackknife (Jack1) [54], mainly because these estimators are less biased than other approaches $[55,56]$. $\beta$-diversity was estimated using the Sørensen coefficient because it (i) excludes joint absences; (ii) allows direct comparisons across studies [57]; and (iii) can be partitioned to identify two opposing processes in $\beta$-diversity patterns: species replacement and species loss [58]. We tested the null hypothesis that variability in $\alpha$-diversity within each of the shelf and bathyal zones was the same, using Levene's Test [59]. Then, we tested the null hypothesis that $\alpha$-diversity was equal between the zones, using a two-way analysis of variance (ANOVA) based on permutations [60], using zones and cruises as orthogonal fixed factors.

Because we lacked sampling replicates at each site, the sampling sites within depth zones were treated as replicates, implying that the spatial variability at the scale of sites is indistinguishable from the sampling error. Differences in $\gamma$-diversity across zones of the PFB was tested using the Welch test, a $t$-test adjusted for heterogeneous variances [59]. This test was applied to each of the estimators of species $\gamma$-diversity (i.e., Chao2 and Jack1). Differences in $\beta$-diversity between the two zones (i.e., continental shelf and bathyal) was tested using a multivariate dispersion test (PERMDISP), using the site $\times$ site matrix of Sørensen dissimilarities [53]. In this case, the null hypothesis was homogeneity in the multivariate dispersions among sites in each of the two zones. Finally, differences in species composition between zones and cruises were tested using Permutational Multivariate Analysis of Variance (PERMANOVA) [61]. Of particular interest was to test the interaction zones $\times$ cruises, having as the null hypothesis that difference in species composition across zones was constant in both cruises. The $p$-values for the F-ratio in the ANOVA, the F-ratio of the univariate and multivariate Levene's tests, as well as for the pseudo-F-ratio of PERMANOVA were obtained by 9999 permutations of residuals under the reduced model. Additionally, the matrix of Sørensen dissimilarities was partitioned into two separate components, spatial turnover (i.e., species loss) and nestedness of species (i.e., species replacement), using the approach of [58]. To identify groups of common species across zones, hierarchical cluster analysis of species was performed based on Whittaker's Index of Association. Then, a shade plot, i.e., heat map, was used to represent those groups of species according to the zone in which they appear [62].

To evaluate the potential structuring of the spatial processes, a multivariate autocorrelation test based on permutations (9999) was applied using the geographic distances between sites (using the Euclidean distance to the geographic coordinates) against the Sørensen dissimilarities matrix [63]. The null hypothesis was that there is no relationship among Sørensen dissimilarities and the spatial proximity of sites. Statistical analyses were performed with the software Primer v.7 \& PERMANOVA+ and with R [64], using the packages vegan [65] and betapart [66].

\section{Results}

\subsection{Taxonomic Composition}

We identified a total of 301 bivalve specimens belonging to 20 families, 28 genera and 39 species (Table 2). Photographs of the 39 species are in Figures 2-5. A checklist, with information about geographic distribution, is provided in Appendix A. The most abundant species were Caryocorbula contracta (Say, 1822) (52 specimens), Saccella acuta (Conrad, 1831) (53 specimens), and Caryocorbula dietziana (C.B. Adams, 1852) (25 specimens). Based on the range of occurrences, the most ubiquitous species was Sacella acuta (14 sampling sites). Eight species were recorded in deeper waters (Sacella concentrica, Anadara secticostata, Bathyarca glomerula, Limopsis sulcata, Isognomon bicolor, Chione sp., Macoploma extenuata, 
and Caryocorbula contracta) and five species in shallower depths (Katedesmia polita, Tindaria amabilis, Hyalopecten strigillatus, Macoploma extenuata, and Cuspidaria rostrate). Most families (i.e., Astartidae, Myidae, Mytilidae, Neilonellidae, Pectinidae, Poromyidae, Pteriidae, Thyasiridae, Veneridae, and Yoldidae) were represented by one to three species.

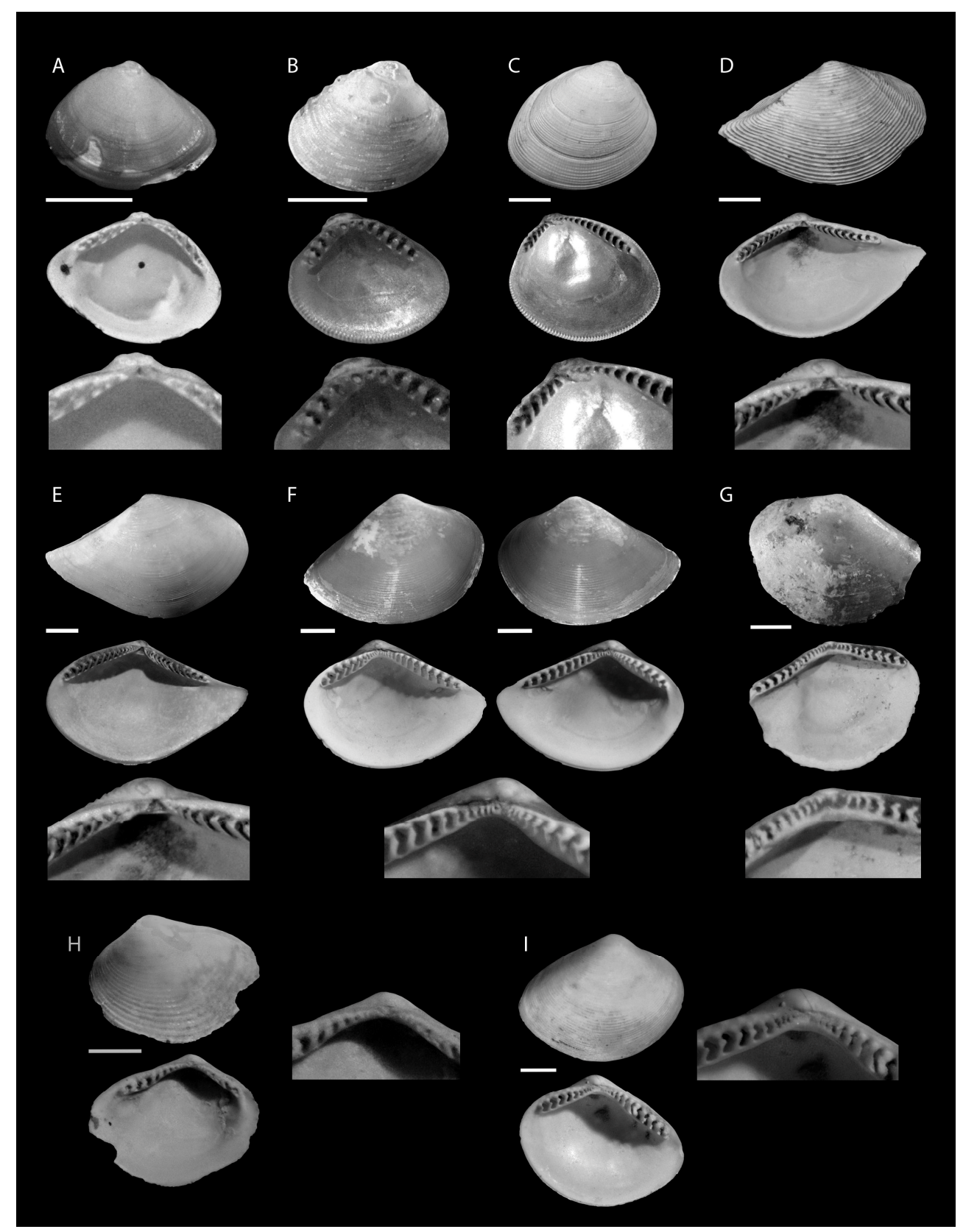

Figure 2. (A) Nucula callicrederma; (B) Nucula culebrensis; (C) Nucula proxima; (D) Saccella acuta; (E,F) Saccella concentrica; (G) Katadesmia polita; (H) Neilonella sp.; (I) Tindaria amabilis. Scale bars = $1 \mathrm{~mm}$. 


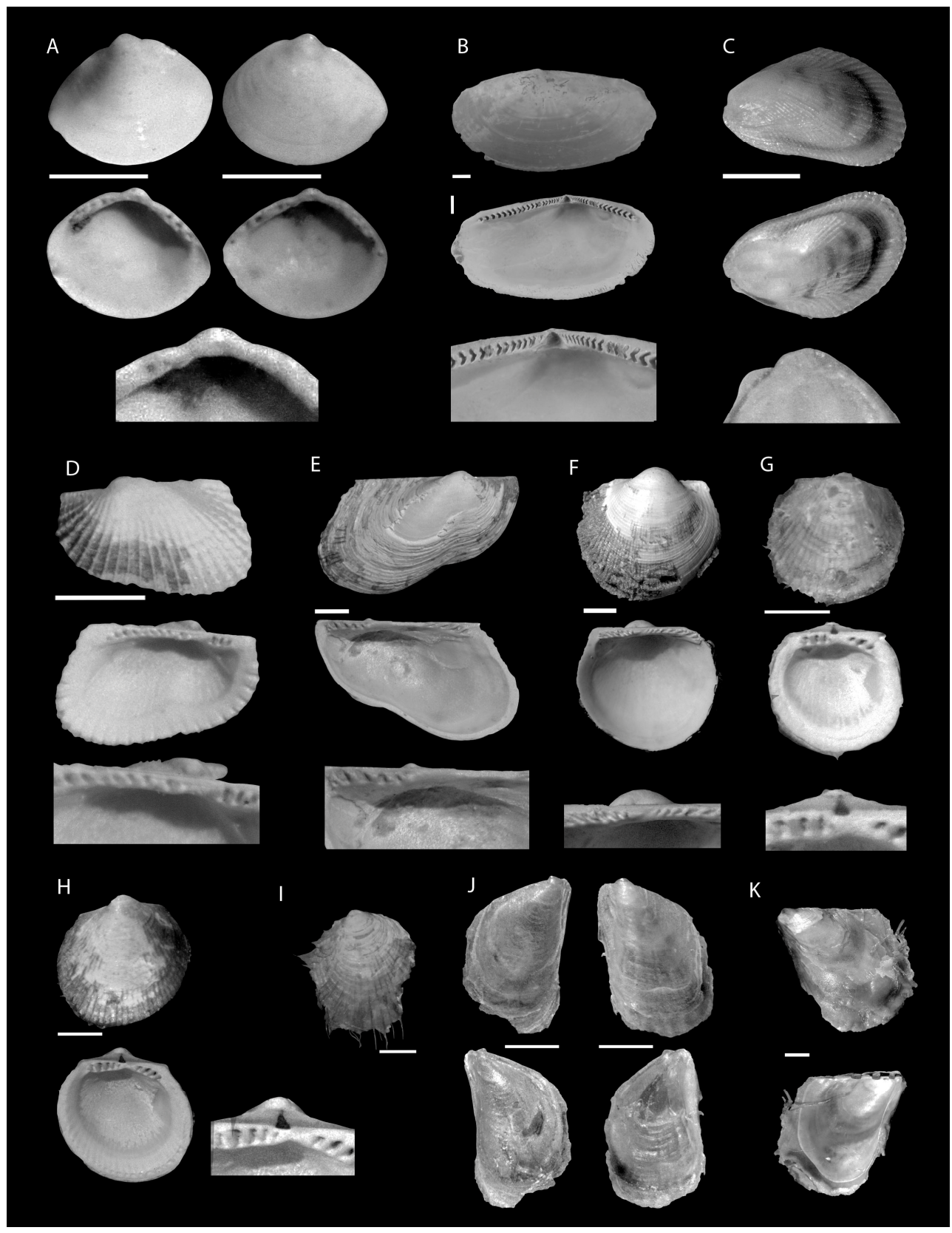

Figure 3. (A) Tindaria sp.; (B) Orthoyoldia solenoides; (C) Brachidontes sp.; (D) Anadara secticostata; (E) Bentharca asperula; (F) Bathyarca glomerula; (G) Limopsis cristata; (H) Limopsis sulcata; (I). Limopsis sp.; (J,K) Isognomon bicolor. Scale bars $=1 \mathrm{~mm}$. 


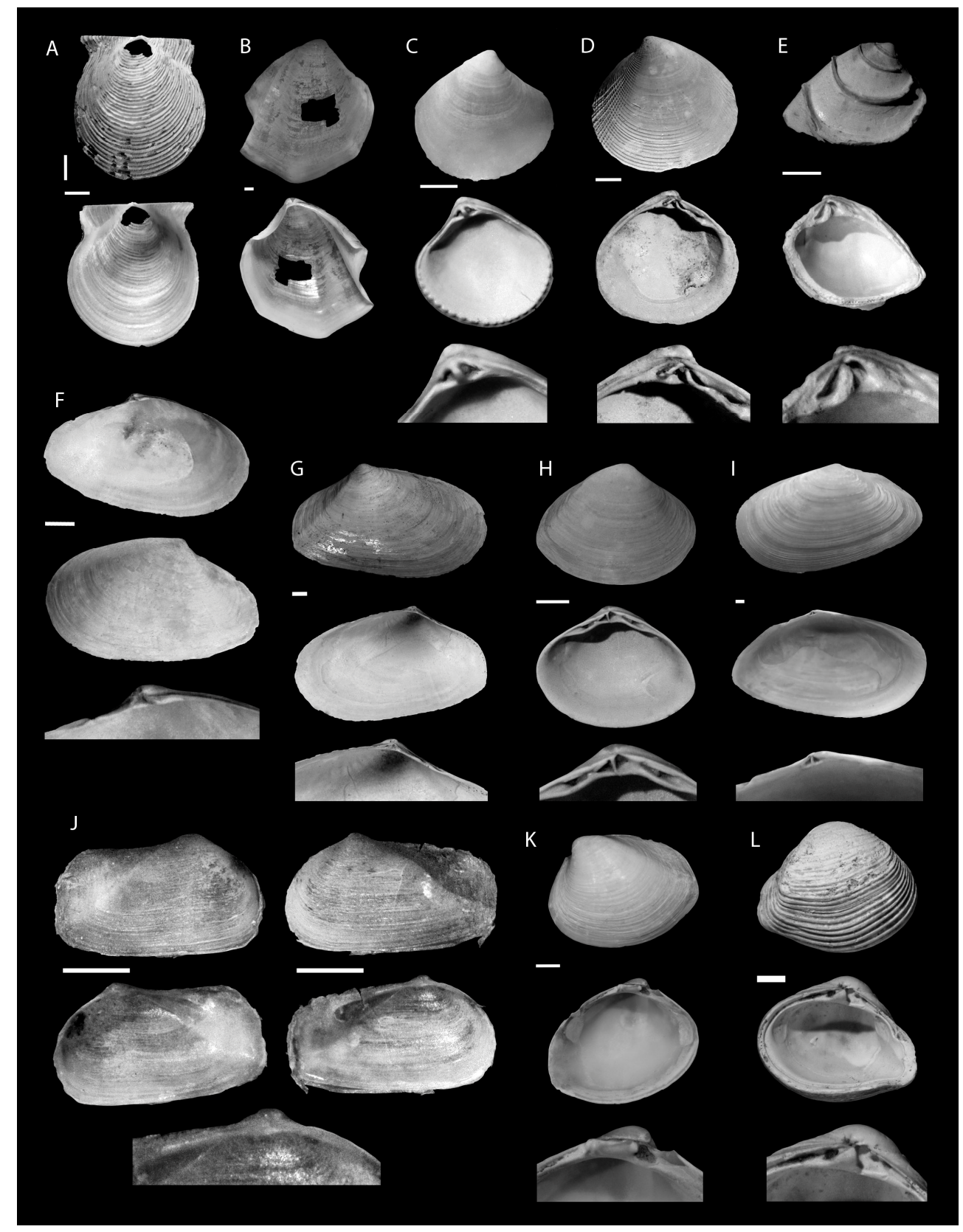

Figure 4. (A) Hyalopecten strigillatus; (B) Thyasira trisinuata; (C) Astarte sp.; (D). Microcardium sp.; (E) Chione sp.; (F) Macoploma exteuata; (G) Macoploma tageliformis; (H) Macoma sp.; (I). Eurytellina niten; (J) Sphenia sp.; (K) Caryocorbula contracta; (L) Caryocorbula dietziana. Scale bars $=1 \mathrm{~mm}$. 


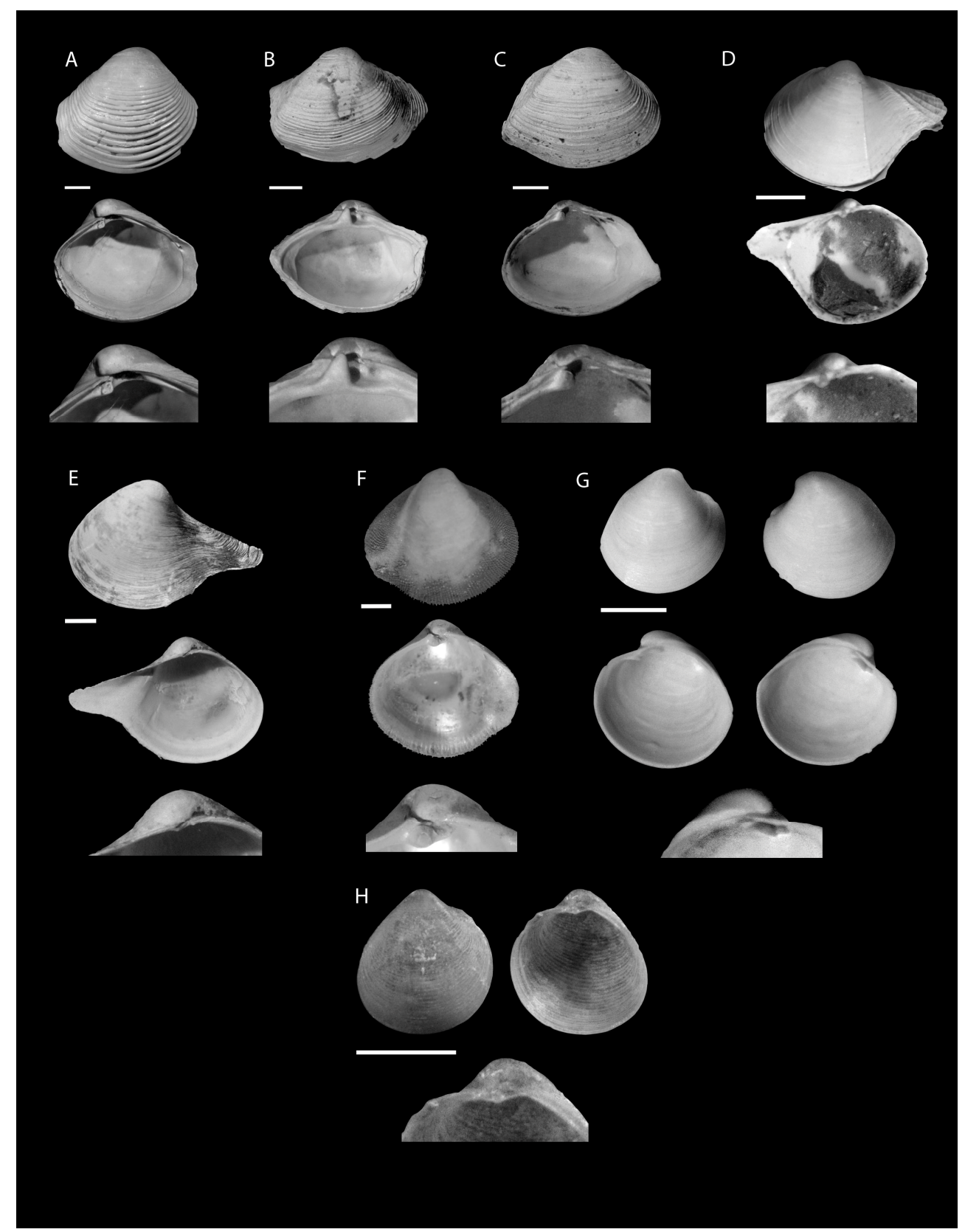

Figure 5. (A) Varicorbula limatula; (B) Corbula sp.; (C) Juliacorbula aequivalvis; (D) Cardiomya sp.; (E) Cuspidaria rostrata; (F) Poromya rostrata; (G) Poromyidae sp. 1.; (H) Poromyidae sp. 2. Scale bars $=1 \mathrm{~mm}$. 
Table 2. List of the 20 bivalve families and 39 species collected during the Perdido 3 and 4 cruises, live (L) whole animal with two valve and with soft parts, versus dead (D), i.e., the shell only. Details on stations and scientific collection vouchers for each specimen can be found in Appendix A.

\begin{tabular}{|c|c|c|c|c|}
\hline Family & Species (L/D) & Sites Perdido 3 & Sites Perdido 4 & Zonation \\
\hline Nuculidae Gray 1824 & $\begin{array}{c}\text { Nucula callicredemna Dall } 1890 \text { (D) } \\
\text { Nucula culebrensis E. A. Smith } 1885 \text { (D) } \\
\text { Nucula proxima Say } 1822 \text { (D) }\end{array}$ & $\begin{array}{l}\text { D4 } \\
\text { B3, C3 } \\
\text { B2 }\end{array}$ & & $\begin{array}{l}\text { Bathyal } \\
\text { Bathyal } \\
\text { Shelf }\end{array}$ \\
\hline $\begin{array}{l}\text { Nuculanidae H. Adams } \\
\text { and A. Adams } 1858 \text { (1854) }\end{array}$ & $\begin{array}{l}\text { Saccella acuta (Conrad 1831) (D) } \\
\text { Saccella concentrica (Say 1824) (D) }\end{array}$ & $\begin{array}{l}\mathrm{C} 1, \mathrm{~B} 1, \mathrm{C} 2, \mathrm{D} 1, \mathrm{~B} 2, \mathrm{D} 2 \\
\mathrm{~B} 3, \mathrm{D} 1, \mathrm{C} 1, \mathrm{~F} 1, \mathrm{D} 1, \mathrm{~B} 1\end{array}$ & $\begin{array}{c}\mathrm{D} 1, \mathrm{D} 2, \mathrm{~F} 2, \mathrm{D} 6, \mathrm{C} 1, \mathrm{~B} 1 \\
\mathrm{~B} 2, \mathrm{C} 2\end{array}$ & $\begin{array}{l}\text { Shelf and bathyal } \\
\text { Shelf and bathyal }\end{array}$ \\
\hline $\begin{array}{l}\text { Malletiidae H. Adams } \\
\text { and A. Adams } 1858\end{array}$ & Katadesmia polita (Verrill and Bush 1898) (D) & $\mathrm{C} 1$ & F3, F4 & Shelf and bathyal \\
\hline $\begin{array}{c}\text { Neilonellidae Schileyko } \\
1989\end{array}$ & Neilonella sp. & C5, D5 & B6 & Bathyal \\
\hline $\begin{array}{l}\text { Tindariidae Verrill and } \\
\text { Bush } 1897\end{array}$ & $\begin{array}{c}\text { Tindaria amabilis (Dall 1889) (D) } \\
\text { Tindaria sp. (D) } \\
\text { aff. Tindaria (D) }\end{array}$ & $\begin{array}{l}\text { F3, C7 } \\
\text { B5 } \\
\text { D4 }\end{array}$ & $\begin{array}{l}\text { B5, B3 } \\
\text { Chapo }\end{array}$ & $\begin{array}{l}\text { Bathyal } \\
\text { Bathyal } \\
\text { Bathyal }\end{array}$ \\
\hline Yoldiidae Dall 1908 & Orthoyoldia solenoides (Dall 1881) (L/D) & $\mathrm{F} 2, \mathrm{C} 2, \mathrm{C} 6, \mathrm{D} 1$ & $\mathrm{~F} 2, \mathrm{C} 2$ & Shelf and bathyal \\
\hline $\begin{array}{c}\text { Mytilidae Rafinesque } \\
1815\end{array}$ & Brachidontes sp. (D) & & D1, E7, F8 & Shelf and bathyal \\
\hline Arcidae Lamarck 1809 & $\begin{array}{l}\text { Anadara secticostata (Reeve 1844) (D) } \\
\text { Bentharca asperula (Dall 1881) (D) } \\
\text { Bathyarca glomerula (Dall 1881) (L/D) }\end{array}$ & $\begin{array}{l}\mathrm{B} 4, \mathrm{C} 2, \mathrm{D} 2 \\
\mathrm{D} 6\end{array}$ & $\begin{array}{c}\text { C5 } \\
\text { Chapo, B5, F4, F8 }\end{array}$ & $\begin{array}{l}\text { Shelf and bathyal } \\
\text { Bathyal } \\
\text { Bathyal }\end{array}$ \\
\hline Limopsidae Dall 1895 & $\begin{array}{c}\text { Limopsis cristata Jeffreys } 1876 \text { (D) } \\
\text { Limopsis sulcata Verrill and Bush } 1898 \text { (D) } \\
\text { Limopsis sp. (D) }\end{array}$ & $\begin{array}{l}\mathrm{B} 4 \\
\mathrm{C} 4, \mathrm{D} 4, \mathrm{~B} 6 \\
\mathrm{C} 4\end{array}$ & $\begin{array}{l}\text { C6, B6, B5 } \\
\text { B3 }\end{array}$ & $\begin{array}{l}\text { Bathyal } \\
\text { Bathyal } \\
\text { Bathyal }\end{array}$ \\
\hline $\begin{array}{l}\text { Pteriidae Gray } 1847 \\
\text { (1820) }\end{array}$ & Isognomon bicolor (C.B. Adams 1845) (D) & & $\mathrm{F} 2, \mathrm{D} 2$ & Shelf \\
\hline $\begin{array}{c}\text { Pectinidae Rafinesque } \\
1815\end{array}$ & Hyalopecten strigillatus (Dall 1889) (D) & B6 & B1 & Shelf and bathyal \\
\hline $\begin{array}{c}\text { Thyasiridae Dall } 1900 \\
\text { (1895) }\end{array}$ & Thyasira trisinuata (d'Orbigny 1853) (D) & B3 & & Bathyal \\
\hline $\begin{array}{c}\text { Astartidae d'Orbigny } \\
1844 \text { (1840) }\end{array}$ & Astarte sp. (D) & C5, B6, D5 & B5, Chapo, C5, B1, F4 & Shelf and bathyal \\
\hline Cardiidae Lamarck 1809 & Microcardium sp. (D) & B2 & & Shelf \\
\hline $\begin{array}{l}\text { Veneridae Rafinesque } \\
1815\end{array}$ & Chione sp. (D) & & C5 & Bathyal \\
\hline Tellinidae Blainville 1814 & $\begin{array}{c}\text { Macoploma extenuata (Dall 1900) (L/D) } \\
\text { Macoploma tageliformis (Dall 1900) (D) } \\
\text { Macoma sp. (D) } \\
\text { Eurytellina nitens (C.B.Adams 1845) (D) }\end{array}$ & $\begin{array}{l}\text { D1, C4 } \\
\text { C1 } \\
\text { B1 }\end{array}$ & $\mathrm{F} 2$ & $\begin{array}{l}\text { Shelf and bathyal } \\
\text { Shelf } \\
\text { Shelf } \\
\text { Shelf }\end{array}$ \\
\hline Myidae Lamarck 1809 & Sphenia sp. (D) & & F1, D3, B5, E7, F8, F5 & Shelf and bathyal \\
\hline Corbulidae Lamarck 1818 & $\begin{array}{c}\text { Caryocorbula contracta (Say 1822) (D) } \\
\text { Caryocorbula dietziana (C.B. Adams 1852) (D) } \\
\text { Varicorbula limatula (Conrad 1846) (D) } \\
\text { Corbula sp. (D) } \\
\text { Juliacorbula aequivalvis (Philippi 1836) (D) }\end{array}$ & $\begin{array}{l}\mathrm{B} 1, \mathrm{C} 1, \mathrm{~F} 1, \mathrm{D} 1, \\
\mathrm{~B} 2, \mathrm{~F} 2, \mathrm{~B} 1, \mathrm{D} 2\end{array}$ & $\begin{array}{l}\mathrm{F} 1, \mathrm{~F} 2, \mathrm{~B} 1, \mathrm{C} 1 \\
\mathrm{D} 2, \mathrm{D} 1 \\
\mathrm{C} 1 \\
\mathrm{D} 1\end{array}$ & $\begin{array}{l}\text { Shelf } \\
\text { Shelf } \\
\text { Shelf } \\
\text { Shelf } \\
\text { Shelf }\end{array}$ \\
\hline Cuspidariidae Dall 1886 & $\begin{array}{c}\text { Cardiomya sp. (D) } \\
\text { Cuspidaria rostrata (Spengler 1793) (D) }\end{array}$ & $\begin{array}{c}\mathrm{D} 2 \\
\mathrm{C} 2, \mathrm{D} 2\end{array}$ & $\mathrm{~F} 2, \mathrm{C} 2$ & $\begin{array}{l}\text { Shelf } \\
\text { Shelf }\end{array}$ \\
\hline Poromyidae Dall 1886 & $\begin{array}{c}\text { Poromya rostrata Rehder } 1943 \text { (D) } \\
\text { Poromyidae sp. } 1 \text { (D) } \\
\text { Poromyidae sp. } 2 \text { (D) }\end{array}$ & $\mathrm{C} 2$ & $\begin{array}{l}\text { B6 } \\
\text { C2 }\end{array}$ & $\begin{array}{l}\text { Shelf } \\
\text { Bathyal } \\
\text { Shelf }\end{array}$ \\
\hline
\end{tabular}

\subsection{Patterns of $\alpha$ - and $\gamma$-Diversity}

For samples collected during both cruises, the bivalve $\alpha$-diversity was consistently significantly higher at shelf sites than at bathyal sites (Table 3) (Table 4A, two-way ANOVA, factor zones, $p<0.05)$. Species richness ranged from $1-7 \mathrm{spp} /$ site $(\mathrm{sd}=1.5 \mathrm{spp} / \mathrm{site})$ in the shelf sites, and from $1-5 \mathrm{spp} /$ site in the bathyal sites ( $\mathrm{sd}=1.1 \mathrm{spp} / \mathrm{site}$ ), but there was no 
statistically significant difference between sites within a zone (Levene test, Fzones $=1.90$, $p>0.05)$. There was also no statistical difference when $\gamma$-diversity between zones was considered (Welch test, Chao2 $=1.87$ with $\mathrm{df}=19.82$ and Jack $1=0.10$ with $\mathrm{df}=17.00$, both $p>0.05)$.

Table 3. Components of bivalve species diversity in the continental shelf and bathyal zones of the Perdido Fold Belt (PFB). Included are the number of sample sites (n), $\alpha$-diversity, Multivariate dispersion (MVD), observed species (Sobs), and $\gamma$-diversity.

\begin{tabular}{ccccccc}
\hline & \multicolumn{1}{c}{$\alpha$-Diversity $( \pm$ SD) } & $\beta$-Diversity (MVD) & \multicolumn{3}{c}{$\gamma$-Diversity } \\
\hline Zone & $n$ & & & Sobs & Chao2 $( \pm$ SE) & Jack1 $( \pm$ SE) \\
\hline Shelf & 16 & $3.9 \pm 1.5$ & 50 & 25 & $77.7 \pm 46.7$ & $39.1 \pm 4.5$ \\
Bathyal & 26 & $2.0 \pm 1.1$ & 64 & 24 & $35.5 \pm 8.8$ & $35.5 \pm 4.1$ \\
\hline
\end{tabular}

Table 4. Spatial-temporal differences in $\alpha$-diversity and species composition based on Sørensen dissimilarities detected with a two-factor linear model, using ANOVA (A) and PERMANOVA (B), respectively. In both, the probability of pseudo-F was estimated using 9999 permutations of residuals under the reduced model. The square roots of the variance components $(\sqrt{ } \mathrm{CV})$ are shown.

\begin{tabular}{lcccccc}
\hline A & \multicolumn{1}{c}{} & & & & \\
\hline Source & $\mathrm{df}$ & $\mathrm{SS}$ & $\mathrm{MS}$ & Pseudo- $F$ & $p$ & $\sqrt{ } \mathrm{CV}$ \\
\hline Cruise & 1 & 0.64 & 0.64 & 0.39 & 0.534 & 0 \\
Zonation & 1 & 35.72 & 35.72 & 21.59 & 0.001 & 1.31 \\
Cruise $\times$ Zonation & 1 & 0.17 & 0.17 & 0.10 & 0.771 & 0 \\
Residuals & 38 & 62.88 & 16.55 & & & 1.29 \\
Total & 41 & 99.62 & & & & \\
\hline B & & & & & & \\
\hline Source & $\mathrm{df}$ & $\mathrm{SS}$ & $\mathrm{MS}$ & Pseudo- $F$ & $p$ & $\sqrt{ } \mathrm{CV}$ \\
\hline Cruise & 1 & 6774.4 & 6774.4 & 1.83 & 0.025 & 12 \\
Zonation & 1 & 25261 & 25261 & 6.83 & 0.001 & 33 \\
Cruise $\times$ Zonation & 1 & 4472.3 & 4472.3 & 1.21 & 0.240 & 9 \\
Residuals & 38 & $1.41 \times 10^{9}$ & 3699.6 & & & 61 \\
Total & 41 & $1.77 \times 10^{9}$ & & & & \\
\hline
\end{tabular}

\subsection{Patterns of $\beta$-Diversity}

Multivariate dispersion was consistently higher on the bathyal than on the continental shelf (PERMDSIP, Fzones $=28.17, p>0.05$, Table 3, Figure 6). This figure illustrates the higher variability in species composition for sites from the bathyal zone (i.e., greater MVD), but the opposite on the continental shelf, i.e., greater similarity among sites.

In general, the partition of the multi-site Sørensen coefficient (0.965) indicated that most $\beta$-diversity corresponds to replacement of species (0.947), rather than a loss of taxa (0.018), with increasing water depth (Figure 7). Species composition showed significant differences between zones (two-way PERMANOVA, factor Zonation, $p<0.05$, Table 4B) and cruises (two-way PERMANOVA, factor Cruise, $p<0.05$, Table 4B). The two factors were shown to be independent (interaction FCruise $\times$ Zonation $=1.22, p>0.05$ ), but the effect of zone size (interpreted from the $\sqrt{ } \mathrm{CV}$ ) was considerably higher than that of cruise. There was no relationship between species composition and spatial distance among sites $(\varrho=0.1, p>0.05)$. 


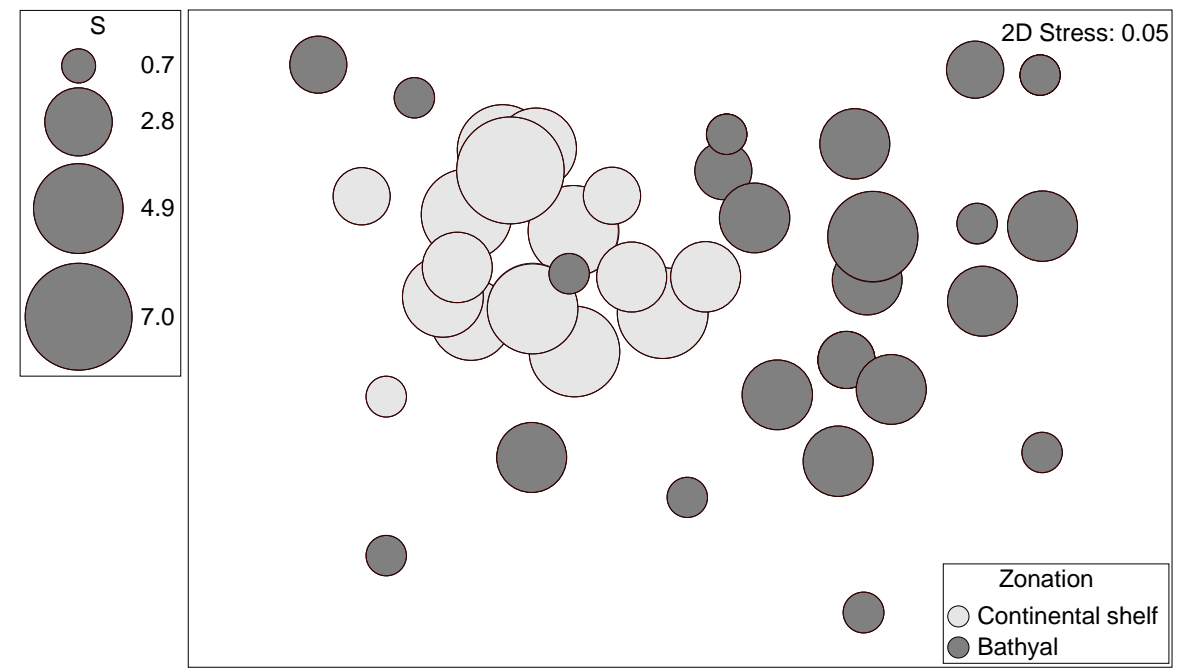

Figure 6. Non-Metric Multidimentional Scaling (nMDS) based on Sørensen dissimilarities among sites on the continental shelf $(<200 \mathrm{~m})$ and bathyal zone $(>200 \mathrm{~m})$ of the PFB, northwest Gulf of Mexico. The size of the circles indicates the number of species registered at each site.

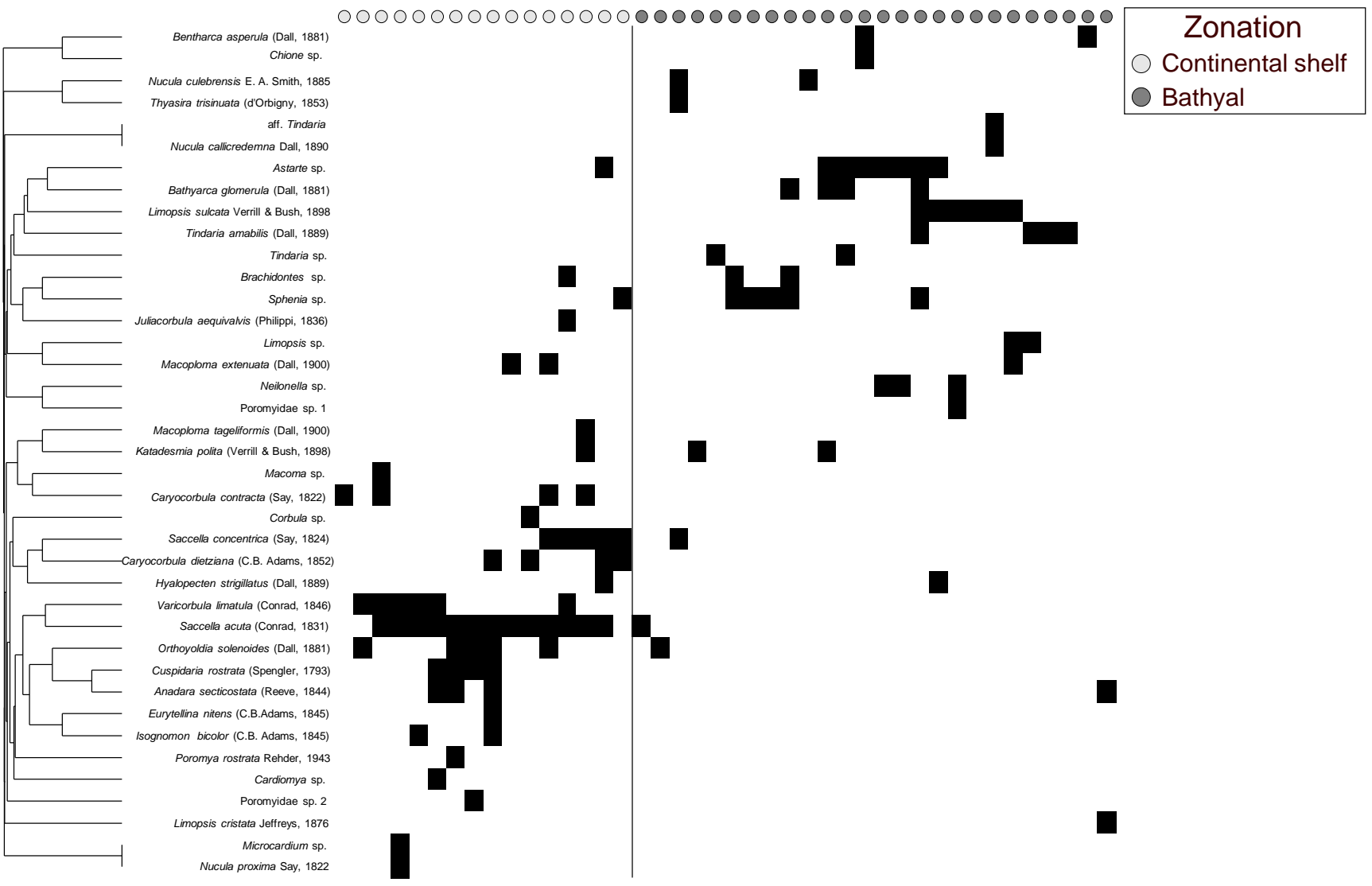

Figure 7. Shade plot for the 29 sites of the Perdido 3 cruise (June) and Perdido 4 cruise (September) 2017, dividing the data by water depth (light grey: continental shelf, 43-200 m; dark gray: bathyal, 375-3563 m), and species similarities or cluster analysis (left tree) of species was performed using the Whittaker's Index of Association.

\section{Discussion \\ 4.1. Faunal Composition}

This study provides new information about bivalve species richness off the coast of Tamaulipas, Mexico, and yielded the first bivalve species list for the deeper zones of the PFB, complementing the earlier study of benthic macrofauna in the PFB [40]. Live bivalves 
were extremely rare, with only a single live specimen for each species of Bathyarca glomerula, Macoploma extenuata, and Orthoyoldia solenoides, collected on both the continental shelf and bathyal.

Species found on the shelf of the PFB had taxonomic affinities with those from the shallow coastal zone of Tamaulipas. Specifically, six species (Nucula proxima, Saccella acuta, S. concentrica, Limopsis cristata, Macoploma tageliformis, and Caryocorbula contracta) were reported from this region by Correa-Sandoval and Rodríguez-Castro [67]. We also collected Orthoyoldia solenoides in this study, which has been found in the GOM from Tampico to Matamoros [68,69]. Species Saccella acuta, Limopsis sulcata, and Poromya rostrate have been reported from deeper waters of the Campeche Bank [70]. Caryocorbula contracta and Saccella acuta were the species with the highest number of specimens collected, 57 and 52, respectively, especially at sites near the coast, adjacent to the Laguna Madre. Eight genera (Nucula, Malletia, Neilonella, Tindaria, Bathyarca, Limopsis, Astarte, and Cuspidaria) found in the PFB were reported by Wei et al. [2,37] from the northern GOM.

Renewed interest in exploitation of deep-sea ecosystems (e.g., oil extraction) has created a race against time for researchers to inventory deep-sea fauna and explore the spatial distribution of species, the processes that sustain them, and the use of benthic taxa as potential indicators of oil spills. Some families of bivalves found in this study have been registered as apparently sensitive (Nuculanidae), cosmopolitan (Nuculidae), and tolerant (Thyasiridae) of deep-sea hydrocarbon blowouts (e.g., Deepwater Horizon oil spill) [71]. This study constitutes an initial effort to document bivalve mollusk diversity on the PFB before it is changed by human activities.

\subsection{Insights from Death Assemblages}

There has been considerable discussion about the representativeness of death assemblages as surrogates for regional biodiversity of mollusks [22,70,71]. Most of the shells in this study were in excellent condition, with morphologic details well preserved. Only three species showed signs of abrasion (Figures 2-5), suggesting that shells of bivalves sampled in the PFB represent modern mollusk diversity in the region.

Previous studies $[22,27,40,72]$ also found very low numbers of live bivalve mollusks in these types of habitats, made no distinction between live and dead specimens, and covered a huge area $[39,73,74]$. Simply because its enormous size, there is a lack of detailed information about the geographical distribution of bivalves across important regions of the Mexican part of the PFB. Results presented here fill such information gaps, with data on the diversity and composition of bivalve communities derived from death assemblages. More taxonomic research and more sampling are needed to explore patterns at finer spatial and bathymetric scales. The study of Wei et al. [2] provides a good example. They collected 271 box-corer samples from 51 stations, which yielded 8055 live bivalve specimens from the deep northern GOM.

\subsection{Spatial Patterns of Species Diversity and Potential Drivers of Variation}

The $\gamma$-diversity is similar between the continental shelf and bathyal zones, but it seems that the processes that maintain such species richness differ between the two regions. Our results suggest that over the water depth range on the continental shelf, $\gamma$-diversity apparently is generated by a combination of high $\alpha$-diversity and low $\beta$-diversity. On the other hand, deeper-water habitats are characterized by low $\alpha$-diversity and high $\beta$ diversity. Such patterns might reflect spatial differences in nutrient input to the benthic zone from surface production, and topographic differences between the two zones. On the continental shelf, there is high primary production as a consequence of nutrient availability, whereas the bathyal zone is characterized by low rates of organic carbon flux $[12,75,76]$. Furthermore, there are marked differences in the geomorphology of the two zones, with the continental shelf possessing a largely flat, mud bottom, and the bathyal having a broad range of water depths with diverse habitat types of different sizes and degrees of separation/connectivity. Relatively high primary production might provide enough 
energy to sustain bivalve assemblages on the continental shelf, with a low rate of species replacement. This suggests that species interactions such as predation and competition may be important factors that shape these communities. For example, bivalves are usually the third-most abundant group of macrofauna $[2,40]$. With their numerical dominance, bivalves are a major food source for asteroids and decapod crustaceans [2].

In contrast to the shelf, nutrient supply might be lower in the bathyal zone, but habitat heterogeneity may facilitate replacement of species with different niche breadth [77], which could explain Bivalvia assemblages from deep-water sites with $\gamma$-diversity equivalent to that estimated for the continental shelf. Similar patterns have been described for seamounts [78], and interpreted in terms of variation in $\alpha$-diversity related to water depth $[77,79,80]$. We suggest that in our study region, the processes that sustain species replacement within each water-depth range differ, but result in similar $\gamma$-diversity values for the two zones of the PFB. $\beta$-diversity in the deep sea has been defined as the spatial replacement of species along depth gradients [81]. This process has been associated with sporadic nutrient pulses that arrive from the continental shelf and that accumulate in the rifts, fissures, channels, or folds of the PFB [8].

\section{Conclusions}

This study provided a taxonomic and ecological baseline for bivalve community composition and diversity in the PFB, and contributed to a better understanding of the complex ecological patterns in the Gulf of Mexico. We demonstrated that death assemblages can help elucidate the diversity of bivalve species on the continental shelf and bathyal zone of the PFB, collected along a gradient of water depth during two cruises. $\alpha$-diversity was significantly higher at continental shelf sites than at bathyal sites, a pattern that has been documented in other deep-sea areas and linked to declining rain of organic inputs with greater water depth. The continental shelf has comparatively low $\beta$-diversity, indicating that sites in the region are similar in term of bivalve diversity. Species replacement contributed more than turnover in shaping the dissimilarity of the bivalve death assemblages. However, the opposite has been found for living organisms in the northern Gulf of Mexico. More investigation would not only improve the resolution of this investigation, but would also resolve uncertainty about the relationship between live and dead bivalve assemblages. We recommended that future studies reduce the number of sampling sites in shallower waters and direct greater sampling effort to deep-water areas. Overall proper assessment of the bivalve fauna in the area will probably involve a much larger sampling effort, and perhaps the use of different sampling techniques, though this will present challenges in terms of cost and time investment. It is necessary to standardize the definition of bathymetric zones to facilitate comparisons among similar studies from sites around the world.

Author Contributions: N.Y.S.-M., E.G.-C. and N.S. conceived of the original idea. N.Y.S.-M. wrote the first draft of the manuscript, identified specimens, and prepared tables and plates. E.G.-C. ran statistical analyses and produced graphics and related tables. N.S. supervised. N.S., E.G.-C., V.M.V.M., M.L.A.-M. and D.P. revised and edited successive drafts of the manuscript. V.M.V.-M., M.L.A.-M. and D.P. were responsible for funding acquisition and project administration. All authors have read and agreed to the published version of the manuscript.

Funding: This research was funded by the National Council of Science and Technology of MexicoMexican Ministry of Energy-Hydrocarbon Trust, project 201441. This is a contribution of the Gulf of Mexico Research Consortium (CIGoM). We acknowledge PEMEX'S specific request to the Hydrocarbon Found to address the environmental effects of oil spills in the Gulf of Mexico.

Institutional Review Board Statement: Not applicable.

Informed Consent Statement: Not applicable.

Data Availability Statement: The data presented in this study are available on request from the corresponding author. 
Acknowledgments: We thank all the scientists, students and crew members who took an active part in the Perdido 3 and 4 cruises, especially Anabel León Hernandez, Sara B. Balan Zetina, Francisco Puc Itza, Carlos Puch, and Juan Pablo Ek Huchim. N.Y.S.-M. is grateful for the financial support provided by the Harte Charitable Foundation, through the Harte Research Institute (Biodiversity of the southern Gulf of Mexico) and by the CONABIO NE018 Project (Update of the knowledge of the diversity of shallow-water benthic marine invertebrate species $(<50 \mathrm{~m})$ from the South of the Gulf of Mexico). We thank Gabriel Cervantes for photographing specimens 3B, 4B and G, and 5F, Raul Castillo for photographing specimens $3 \mathrm{C}$ and $4 \mathrm{I}$, and Julio Duarte and Diana Ugalde for producing the study area map. Mark Brenner helped edit the manuscript. The research was funded by the National Council of Science and Technology of Mexico-Mexican Ministry of Energy-Hydrocarbon Trust, project 201441. This is a contribution of the Gulf of Mexico Research Consortium (CIGoM). We are very grateful to Editor Mario Pei. We also thank the three anonymous reviewers for their helpful comments and suggestions.

Conflicts of Interest: The authors declare no conflict of interest.

\section{Appendix A. Taxonomic List of the Identified Species}

Family Nuculidae Gray, 1824

Nucula callicredemna Dall, 1890

Figure 2A

Material examined. Perdido 3, St. D4, 960 m, 1 empty shell (CMPY-001153).

Overall geographic range. This species has recently been reported in deep waters in the eastern Gulf of Mexico, off Trinidad and Tobago, and Brazil, at depths of 1609-3731 m, benthic and infaunal [39].

Nucula culebrensis E. A. Smith, 1885

Figure 2B

Material examined. Perdido 3, St.B3, 514 m, 1 empty shell (CMPY-001123) and St. C3, 508 m, 1 empty shell (CMPY-001199).

Overall geographic range. This species has been reported in Texas, the Gulf of Mexico, and Puerto Rico, at depths of 417-1518 m [38].

Nucula proxima Say, 1822

Figure 2C

Material examined. Perdido 3, St. B2, 48.8 m, 2 empty shells (CMPY-001122).

Overall geographic range. The species occurring in Nova Scotia, Canada to Florida, and Texas, Bermuda, at depths of 0-124 m, benthic and infaunal [39].

Family Nuculanidae H. Adams and A. Adams, 1858 (1854)

Saccella acuta (Conrad, 1831)

Figure 2D

Material examined. Perdido 3, St. C1, 46.23 m, 1 empty shell (CMPY-001093), St. B1, 49.67 m, 1 empty shell (CMPY-001112) and 1 empty shell (CMPY-001119), St. C2, 98 m, 2 empty shells (CMPY-001253), 8 empty shells (CMPY-001138) and 1 empty shell (CMPY-001146), St. D1, 43 m, 1 empty shell (CMPY-001151), St. B2, 48.8 m, 2 empty shells (CMPY-001165), St. D2, 200 m, 3 empty shells (CMPY-001198) and 2 empty shells (CMPY-001200). Perdido 4, St. D1, 43.48 m, 1 empty shell (CMPY-002380), St. D2, 107.6 m, 1 empty shell (CMPY-002384) and 2 empty shells (CMPY-002438), St. F2, $93.38 \mathrm{~m}, 2$ empty shells (CMPY-002440) and 3 empty shells (CMPY-002441), St. D6, 1660 m, 1 empty shell (CMPY-002439), St. C1, 48.23 m, 1 empty shell (CMPY-002378), 2 empty shells (CMPY-002434) and 1 empty shell (CMPY002435), St. B1, $51.52 \mathrm{~m}, 1$ empty shell (CMPY-002379), 1 empty shell (CMPY-002431) and 1 empty shell (CMPY-002432), St. B2, 96 m, 4 empty shells (CMPY-002433), St. C2, 104 m, 3 empty shells (CMPY-002436), 3 empty shells (CMPY-002437), and 1 empty shell (CMPY-002442).

Overall geographic range. This species was found in Massachusetts to Campeche Bank, Mexico, West Indies, Brazil, and Cuba in the intervals at 0-274 m, benthic, estuarine, and 
infaunal [39].

Saccella concentrica (Say, 1824)

Figure 2E,F

Material examined. Perdido 3, St. B3, $514 \mathrm{~m}, 2$ empty shells (CMPY-001152), St. D1, 43 m, 3 empty shells (CMPY-001155), St. C1, 46.23 m, 1 empty shell (CMPY-001166). Perdido 4, St. F1, 48.7 m, 4 empty shells (CMPY-002355), St. D1, 43.48 m, 1 empty shell (CMPY-002443) and 8 empty shells (CMPY-002444), St. B1, 51.52, 1 empty shell (CMPY-002377).

Overall geographic range. This species was found in west Florida to Texas, the northwest Gulf of Mexico offshore banks, and Brazil, at 0-90 m depth, benthic, infaunal, seagrass [39].

Family Malletiidae H. Adams and A. Adams, 1858

Katadesmia polita (Verrill and Bush, 1898)

Figure 2G

Material examined. Perdido 3, St. C1, 46.23 m, 1 empty shell (CMPY-001094). Perdido 4, St. F3, 375 m, 1 empty shell (CMPY-002387) and 1 empty shell (CMPY-002447), St. F4, 1378 m, 1 empty shell (CMPY-002454).

Overall geographic range. Previously considered a synonym of Malletia bermudensis Hass, 1949 and Malletia polita Verrill and Bush, 1898.

Family Neilonellidae Schileyko, 1989

Neilonella sp.

Figure 2H

Material examined. Perdido 3, St. C5, 1371 m, 1 empty shell (CMPY-001254), St. D5, 1244 m, 1 empty shell (CMPY-001167). Perdido 4, St. B6, 1774 m, 2 empty shells (CMPY-002451).

Family Tindariidae Verrill and Bush, 1897

Tindaria amabilis (Dall, 1889)

Figure 2I

Material examined. Perdido 3, St. F3, 439 m, 2 empty shells (CMPY-001231), St. C7, 2644 m, 1 empty shell (CMPY-001140). Perdido 4, St. B5, 1543 m, 1 empty shell (CMPY-002367), St. B3, 438 m, 2 empty shells (CMPY-002357).

Overall geographic range. The species occurring in the northwest Gulf of Mexico to the West Indies, Bermuda; Indian Ocean, at depths of 969-1829 m, benthic and infaunal [39].

Tindaria sp.

Figure 3A

Material examined. Perdido 3, St. B5, 1500 m, 1 empty shell (CMPY-001193). Perdido 4, St. Chapo, 1315 m, 1 empty shell (CMPY-002453).

aff. Tindaria

Material examined. Perdido 3, St. D4, 960 m, 2 empty shells (CMPY-001135).

Family Yoldiidae Dall, 1908

Orthoyoldia solenoides (Dall, 1881)

Figure 3B

Material examined. Perdido 3, St. F2, 86.4 m, 1 empty shell (CMPY-001159), St. C2, 98 m, 2 empty shell (CMPY-001091), St. C6, 2080 m, 2 empty shells (CMPY-001130). Perdido 4, St. F2, $93.38 \mathrm{~m}$, 2 empty shells (CMPY-002352), 1 empty shell (CMPY-002373) and 1 empty shell (CMPY-002374), St. C2, 104 m, 2 empty shells (CMPY-002375).

Live specimen. St. D1, 43 m, 1 live specimen (BCC-18082), Perdido 3.

Overall geographic range. Previously considered a synonym of Nucula crosbyana Guppy, 1882 and Orthoyoldia solenoides Dall, 1881. The species occurs from Mississippi to Texas, at 
depths of 91-379 $\mathrm{m}$, benthic and infaunal [39].

Family Mytilidae Rafinesque, 1815

Brachidontes sp.

Figure 3C

Material examined. Perdido 4, St. D1, 43.48 m, 1 empty shell (CMPY-002359), St. E7, 3053, 1 empty shells (CMPY-002452), St. F8, 3563 m, 1 empty shell (CMPY-002358).

Family Arcidae Lamarck, 1809

Anadara secticostata (Reeve, 1844)

Figure 3D

Material examined. Perdido 3, St. B4, 959.5 m, 1 empty shell (CMPY-001117), St. C2, 98 m, 1 empty shell (CMPY-001129), St. D2, 200 m, 3 empty shells (CMPY-001164).

Overall geographic range. Previously considered a synonym of Anadara floridana (Conrad, 1869), Anomalocardia floridana Conrad, 1869, Arca lienosa Say, 1832 sensu Dall, 1886, Arca secticostata Reeve, 1844, and Scapharca crassissima Macsotay, 2001. The species occurs from North Carolina to Yucatan, Mexico, and Greater Antilles, at depths of 0-110 m, benthic, byssate, epibiotic, soft substrate (muds, sands, clays) [39].

Bentharca asperula (Dall, 1881)

Figure 3E

Material examined. Perdido 3, St. D6, 1957 m, 1 empty shell (CMPY-001103). Perdido 4, St. C5, $1267 \mathrm{~m}, 1$ empty shell (CMPY-002385).

Overall geographic range. The species has been reported from Virginia to Florida and the northwest Gulf of Mexico, Cuba, and the Caribbean, at depths of 329-3475 m, benthic, byssate, and epibiotic [39].

Bathyarca glomerula (Dall, 1881)

Figure 3F

Material examined. Perdido 4, St. Chapo, 1315 m, 1 empty shell (CMPY-002351), St. B5, 1543 m, 1 empty shell (CMPY-002376), St. F4, 1378 m, 1 empty shell (CMPY-002350).

Live specimen. St. F8, 3563 m, 1 specimen (BCC-18315), Perdido 4.

Overall geographic range. The species has been reported from North Carolina to southwest Florida, and the West Indies, at depths of 110-509 m, benthic and infaunal [39].

Family Limopsidae Dall, 1895

Limopsis cristata Jeffreys, 1876

Figure 3G

Material examined. Perdido 3, St. B4, 959.5 m, 3 empty shells (CMPY-001197).

Overall geographic range. The species has been reported from Massachusetts to Dry Tortugas and off Texas, at depths of 55-1965 m, benthic, deep sea, and infaunal [39].

Limopsis sulcata Verrill and Bush, 1898

Figure $3 \mathbf{H}$

Material examined. Perdido 3, St. C4, 960 m, 1 empty shell (CMPY-001239), St. D4, 960 m, 4 empty shells (CMPY-001120), St. B6, $1794 \mathrm{~m}, 1$ empty shell (CMPY-001121) and 3 empty shells (CMPY-001162). Perdido 4, St. C6, 1660 m, 1 empty shell (CMPY-002361), St. B6, 1774 m, 1 empty shell (CMPY-002356), St. B5, 1543 m, 2 empty shell (CMPY-002446).

Overall geographic range. The species has been reported from Massachusetts to Campeche Bank, Mexico, and West Indies, at depths of 16-1401 m, benthic, deep sea, infaunal [39].

Limopsis sp.

Figure 3I

Material examined. Perdido 3, St. C4, 960 m, 1 empty shell (CMPY-001118). Perdido 4, St. 
B3, 438 m, 2 empty shells (CMPY-002383).

Family Pteriidae Gray, 1847 (1820)

Isognomon bicolor (C.B. Adams, 1845)

Figure 3J,K

Material examined. Perdido 4, St. F2, 93.38 m, 2 empty shells (CMPY-002353), St. D2, 107.6 m, 1 empty shell (CMPY-002362).

Overall geographic range. The species has been reported from Florida Keys and Dry Tortugas to Yucatan, Mexico, Cuba, West Indies, and Bermuda, at depths of 0-6 m, byssate, epibiotic, hard substrate, and inlet influenced [39].

Family Pectinidae Rafinesque, 1815

Hyalopecten strigillatus (Dall, 1889)

Figure $4 \mathrm{~A}$

Material examined. Perdido 3, St. B6, 1794 m, 1 empty shell (CMPY-001143). Perdido 4, St. B1, $51.52 \mathrm{~m}, 1$ empty shell (CMPY-002354).

Overall geographic range. Formerly in Cyclopecten (Mikkelsen and Bieler, 2008), the species has been reported off East Florida to northwest Gulf of Mexico, Cuba, at depths of 538-2160 $\mathrm{m}$, benthic and epibiotic [39].

Family Thyasiridae Dall, 1900 (1895)

Thyasira trisinuata (d'Orbigny, 1853)

Figure 4 B

Material examined. Perdido 3, St. B3, 514 m, 1 empty shell (CMPY-001137).

Overall geographic range. The species has been reported in Nova Scotia, Canada to northwest Gulf of Mexico, West Indies; Alaska to California, at depths of 14-680 m, benthic; infaunal and soft substrate (muds, sands, clays) [39].

Family Astartidae d'Orbigny, 1844 (1840)

Astarte sp.

Figure $4 \mathrm{C}$

Material examined. Perdido 3, St. C5, 1371 m, 2 empty shells (CMPY-001113), St. B6, 1794 m, 2 empty shells (CMPY-001127) and 2 empty shells (CMPY-001161), St. D5, 1244 m, 1 empty shell (CMPY-001196). Perdido 4, St. B5, 1543 m, 1 empty shell (CMPY-002448), St. Chapo, 1315 m, 2 empty shells (CMPY-002450), St. C5, 1267 m, 1 empty shell (CMPY002360), St. B1, 51.52 m, 2 empty shells (CMPY-002370), St. F4, 1378 m, 2 empty shells (CMPY-002381) and 2 empty shells (CMPY-002449).

Family Cardiidae Lamarck, 1809

Microcardium sp.

Figure 4D

Material examined. Perdido 3, St. B2, 48.8 m, 1 empty shell (CMPY-001128).

Family Veneridae Rafinesque, 1815

Chione sp.

Figure $4 \mathrm{E}$

Material examined. Perdido 4, St. C5, 1267 m, 1 empty shell (CMPY-002363).

Family Tellinidae Blainville, 1814

Macoploma extenuata (Dall, 1900)

Figure $4 \mathbf{F}$

Material examined. Perdido 3, St. D1, 43 m, 2 empty shells (CMPY-001115).

Live specimen. St. C4, $960 \mathrm{~m}, 1$ specimen (BCC-18060), Perdido 3.

Overall geographic range. Previously considered a synonym of Macoma extenuata Dall, 
1900, the species has been reported from Florida Keys to Texas, at depths of 59-128 m, benthic; endemic to Gulf of Mexico and infaunal [39].

Macoploma tageliformis (Dall, 1900)

Figure 4G

Material examined. Perdido 3, St. C1, 46.23 m, 3 empty shells (CMPY-001089).

Overall geographic range. Previously considered a synonym of Macoma tageliformis Dall, 1900, the species has been reported in Florida Keys and Dry Tortugas to Quintana Roo, Mexico, Cuba, and Greater Antilles, Brazil, at depths of 0-49 m, benthic; estuarine and infaunal [39].

Macoma sp.

Figure $4 \mathbf{H}$

Material examined. Perdido 3, St. B1, 49.67 m, 1 empty shell (CMPY-001139).

Eurytellina nitens (C.B. Adams, 1845)

\section{Figure 4I}

Material examined. Perdido 4, St. F2, 93.38 m, 1 empty shell (CMPY-002388).

Overall geographic range. The species has been reported from North Carolina to Texas, Cuba, and Brazil, at depths of 0-120 m, benthic and infaunal [39].

Family Myidae Lamarck, 1809

Sphenia sp.

Figure 4J

Material examined. Perdido 4, St. F1, 48.7 m, 2 empty shells (CMPY-002382), St. D3, 379 m, 1 empty shell (CMPY-002371), St. B5, 1543 m, 1 empty shell (CMPY-002369), St. E7, 3053 m, 2 empty shells (CMPY-002368), St. F8, 3563 m, 1 empty shell (CMPY-002372), St. F5, 1905 m, 1 empty shell (CMPY-002365).

Family Corbulidae Lamarck, 1818

Caryocorbula contracta (Say, 1822)

Figure $4 \mathbf{K}$

Material examined. Perdido 3, St. B1, 49.67 m, 11 empty shells (CMPY-001086), St. C1, 46.23 m, 4 empty shells (CMPY-001114), St. F1, 45.8 m, 4 empty shells (CMPY-001132), St. D1, 43 m, 8 empty shells (CMPY-001134), 22 empty shells (CMPY-001141) and 8 empty shells (CMPY-001131).

Overall geographic range. The species has been reported from Massachusetts to Florida Keys, Texas, Cuba, West Indies, and Brazil, at depths of 0-14 m, benthic and infaunal [39].

Caryocorbula dietziana (C.B. Adams, 1852)

Figure $4 \mathrm{~L}$

Material examined. Perdido 4, St. F1, 48.7 m, 1 empty shell (CMPY-002455), St. F2, 93.38 m, 6 empty shells (CMPY-002456), St. B1, 51.52 m, 2 empty shells (CMPY-002457), 1 empty shell (CMPY-002458) and 4 empty shells (CMPY-002460), St. C1, 48.23 m, 11 empty shells (CMPY-002459).

Overall geographic range. The species has been reported in North Carolina, Gulf of Mexico, Cuba, Jamaica, and Brazil, at depths of 2-101 m, benthic and infaunal [39].

Varicorbula limatula (Conrad, 1846)

Figure 5A

Material examined. Perdido 3, St. B2, 48.8 m, 4 empty shells (CMPY-001116), St. F2, 86.4 m, 3 empty shells (CMPY-001147), St. B1, 49.67 m, 3 empty shells (CMPY-001150), St. D2, 200 m, 4 empty shells (CMPY-001124). Perdido 4, St. D2, 107.6 m, 1 empty shell (CMPY-002461), St. D1, 43.48 m, 1 empty shell (CMPY-002462). 
Overall geographic range. Previously considered a synonym of Corbula disparilis d'Orbigny, 1853, Corbula limatula Conrad, 1846, and Varicorbula disparilis d'Orbigny, 1853, the species has been reported in North Carolina to Texas, Gulf of Mexico offshore banks, Cuba, West Indies, and Brazil, at depths of 0-549 m, benthic and infaunal [39].

Corbula sp.

Figure 5B

Material examined. Perdido 4, St. C1, 48.23 m, 1 empty shell (CMPY-002366).

Juliacorbula aequivalvis (Philippi, 1836)

Figure 5C

Material examined. Perdido 4, St. D1, 43.48 m, 8 empty shells (CMPY-002445).

Overall geographic range. The species has been reported from Florida Straits to Florida Keys, North Gulf of Mexico, Cuba, Antilles, and Central America, at depths of 0-101 m, benthic and infaunal [39].

Cardiomya sp.

Figure 5D

Material examined. Perdido 3, St. D2, 200 m, 1 empty shell (CMPY-001149).

Family Cuspidariidae Dall, 1886

Cuspidaria rostrata (Spengler, 1793)

Figure 5E

Material examined. Perdido 3, St. C2, 98 m, 1 empty shell (CMPY-001125) and 1 empty shell (CMPY-001148), St. D2, 200 m, 1 empty shell (CMPY-001163). Perdido 4, St. F2, 93.38 m, 1 empty shell (CMPY-002348), St. C2, 104 m, 1 empty shell (CMPY-002349).

Overall geographic range. The species has been reported from the Arctic Ocean to Dry Tortugas, northwest Gulf of Mexico, and West Indies, at depths of 119-2926 m, benthic; deep sea and infaunal [39].

Family Poromyidae Dall, 1886

Poromya rostrata Rehder, 1943

Figure 5F

Material examined. Perdido 3, St. C2, 98 m, 1 empty shell (CMPY-001230).

Overall geographic range. The species has been reported from North Carolina to Texas, West Indies, at depths of 0-200 m, benthic and infaunal [39].

Poromyidae sp. 1

Figure 5G

Material examined. Perdido 4, St. B6, 1774 m, 2 empty shells (CMPY-002463).

Poromyidae sp. 2

Figure 5H

Material examined. Perdido 4, St. C2, 104 m, 1 empty shell (CMPY-002464).

\section{References}

1. Bray, R.A. Digenean parasites of deep-sea teleosts: A progress report. Int. J. Parasitol. Parasites Wildl. 2020, 12, 251-264. [CrossRef] [PubMed]

2. Wei, C.L.; Chen, M.; Wicksten, M.K.; Rowe, G.T. Macrofauna bivalve diversity from the deep northern Gulf of Mexico. Ecol. Res. 2020, 35, 343-361. [CrossRef]

3. Zezina, O.N. Biogeography of the bathyal zone. Adv. Mar. Biol. 1997, 32, 389-426. [CrossRef]

4. Snelgrove, P.V.R.; Smith, C.R. A riot of species in an environmental calm: The paradox of the species-rich deep-sea floor. Oceanogr. Mar. Biol. Annu. Rev. 2002, 40, 311-342.

5. Hessler, R.; Sanders, H.L. Faunal diversity in the deep-sea. Deep Sea Res. 1967, 14, 65-78. [CrossRef]

6. Sanders, H.L.; Hessler, R.R. Ecology of the deep-sea benthos. Science 1969, 163, 1419-1424. [CrossRef] [PubMed] 
7. Rex, M.A. Community Structure in the Deep-Sea Benthos. Annu. Rev. Ecol. Syst. 1981, 12, 331-353. [CrossRef]

8. Olabarria, C. Patterns of bathymetric zonation of bivalves in the Porcupine Seabight and adjacent Abyssal plain, NE Atlantic. Deep-Sea Res. Part I 2005, 52, 15-31. [CrossRef]

9. Levin, L.A.; Etter, R.J.; Rex, M.A.; Gooday, A.J.; Smith, C.R.; Pineda, J.; Stuart, C.T.; Hessler, R.R.; Pawson, D. Environmental influences on regional deep-sea species diversity. Annu. Rev. Ecol. Syst. 2001, 32, 51-93. [CrossRef]

10. Hendrickx, M.E. Operaciones oceanográficas realizadas durante el proyecto TALUD en el Pacífico mexicano (1989-2009). In Biodiversidad y Comunidades del Talud Continental del Pacífico Mexicano; Instituto Nacional de Ecología, Secretaria del Medio Ambiente y Recursos Naturales (Semarnat): México City, Mexico, 2012; pp. 23-104.

11. Aguilar, V. Análisis de vacíos y omisiones en conservación de la biodiversidad del mar profundo. In La Frontera Final: El Océano Profundo; Low Pfeng, A., Peters Recargno, E.M., Eds.; INECC: México City, Mexico, 2013; pp. 265-276.

12. Rex, M.A.; Crame, J.A.; Stuart, C.T.; Clarke, A. Large-scale biogeographic patterns in marine mollusks: A confluence of history and productivity? Ecology 2005, 86, 2288-2297. [CrossRef]

13. Rex, M.A.; McClain, C.R.; Johnson, N.A.; Etter, R.J.; Allen, J.A.; Bouchet, P.; Warén, A. A source-sink hypothesis for abyssal biodiversity. Am. Nat. 2005, 165, 163-178. [CrossRef] [PubMed]

14. Bouchet, P.; Lozouet, P.; Maestrati, P.; Heros, V. Assessing the magnitude of species richness in tropical marine environments: Exceptionally high numbers of molluscs at a New Caledonia site. Biol. J. Linn. Soc. 2002, 75, 421-436. [CrossRef]

15. Moretzsohn, F.; Tunnell, W., Jr.; Lyons, W.G.; Baqueiro, E.; Barrera, N.; Espinosa, E.; García, E.F.; Ortea, J.; Regueiro, M. Mollusca: Introduction. In Gulf of Mexico Origin, Waters, and Biota Volume 1, Biodiversity; Felder, D.L., Camp, D.K., Eds.; Texas A\&M University Press: Corpus Christi, TX, USA, 2009; pp. 559-564.

16. McClain, C.R.; Stegen, J.C.; Hurlbert, A.H. Dispersal, environmental niches and oceanic-scale turnover in deep-sea bivalves. Proc. R. Soc. B Biol. Sci. 2012, 279, 1993-2002. [CrossRef]

17. Kamenev, G.M. Bivalve molluscs of the abyssal zone of the Sea of Okhotsk: Species composition, taxonomic remarks, and comparison with the abyssal fauna of the Pacific Ocean. Deep-Sea Res. Part II 2018, 154, 230-248. [CrossRef]

18. Kamenev, G.M. Species composition and distribution of bivalves in bathyal and abyssal depths of the Sea of Japan. Deep-Sea Res. Part II 2013, 86-87, 124-139. [CrossRef]

19. Kamenev, G.M. Composition and distribution of bivalves of the abyssal plain adjacent to the Kuril-Kamchatka Trench (Pacific Ocean). Deep-Sea Res. Part II 2015, 111, 188-197. [CrossRef]

20. Rex, M.A.; Stuart, C.T.; Hessler, R.R.; Allen, J.A.; Sanders, H.L.; Wilson, G.D.F. Global-scale latitudinal patterns of species diversity in the deep-sea benthos. Nature 1993, 365, 636-639. [CrossRef]

21. Bürkli, A.; Wilson, A.B. Explaining high-diversity death assemblages: Undersampling of the living community, out-of-habitat transport, time-averaging of rare taxa, and local extinction. Palaeogeogr. Palaeoclimatol. Palaeoecol. 2017, 466, 174-183. [CrossRef]

22. Grill, B.; Zuschin, M. Modern shallow- to deep-water bivalve death assemblages in the Red Sea-Ecology and biogeography. Palaeogeogr. Palaeoclimatol. Palaeoecol. 2001, 168, 75-96. [CrossRef]

23. Kidwell, S.M.; Tomasovych, A. Implications of Time-Averaged Death Assemblages for Ecology and Conservation Biology. Annu. Rev. Ecol. Evol. Syst. 2013, 44, 539-563. [CrossRef]

24. Kidwell, S.M. Ecological fidelity of open marine molluscan death assemblages: Effects of post-mortem transportation, shelf health, and taphonomic inertia. Lethaia 2008, 41, 199-217. [CrossRef]

25. Kidwell, S.M. Discordance between living and death assemblages as evidence for anthropogenic ecological change. Proc. Natl. Acad. Sci. USA 2007, 104, 17701-17706. [CrossRef] [PubMed]

26. Shantharam, A.K.; Baco, A.R. Biogeographic and bathymetric patterns of benthic molluscs in the Gulf of Mexico. Deep-Sea Res. Part I 2020, 155, 103167. [CrossRef]

27. Gracia, A.; Valentich-Scott, P. New records of soft bottom bivalves (Mollusca) from the continental shelf and upper slope of the northern Pacific Ocean of Colombia. Mar. Biodivers. Rec. 2014, 7. [CrossRef]

28. Janssen, R.; Taviani, M. Taxonomic, Ecological and Historical Considerations on the Deep-Water Benthic Mollusc Fauna of the Red Sea. In The Red Sea; Springer: Berlin/Heidelberg, Germany, 2015; pp. 511-529.

29. Joye, S.B. The Gulf of Mexico ecosystem-Before, during and after the Deepwater Horizon oil well blowout. Deep-Sea Res. Part II 2016, 129, 1. [CrossRef]

30. Salcedo, D.L.; Soto, L.A.; Estradas-Romero, A.; Botello, A.V. Interannual variability of soft-bottom macrobenthic communities of the NW Gulf of Mexico in relationship to the Deepwater Horizon oil spill. Mar. Pollut. Bull. 2017, 114, 987-994. [CrossRef] [PubMed]

31. Ruiz, J.; Uritte, R.; Román, E.; Fkjres, H. El Cinturón Plegado Mexicano. Estructura y Potencial Petrolero. Boletín AMGP 2003, 50, 3-20.

32. Gradmann, S.; Beaumont, C.; Albertz, M. Factors controlling the evolution of the Perdido Fold Belt, northwestern Gulf of Mexico, determined from numerical models. Tectonics 2009, 28. [CrossRef]

33. Chen, M. Community Structure of Deep-Sea Bivalve Mollusks from the Northern Gulf of Mexico; Texas A\&M University: Corpus Christi, TX, USA, 2004.

34. Gustafson, R.G.; Turner, R.D.; Lutz, R.A.; Vrijenhoek, R.C. A new genus and five new species of mussels (Bivalvia, Mytilidae) from deep-sea sulfide/hydrocarbon seeps in the Gulf of Mexico. Malacologia 1998, 40, 63-112. 
35. McVeigh, D.M.; Eggleston, D.B.; Todd, A.C.; Young, C.M.; He, R. The influence of larval migration and dispersal depth on potential larval trajectories of a deep-sea bivalve. Deep-Sea Res. Part I 2017, 127, 57-64. [CrossRef]

36. Vrijenhoek, R.C.; Schutz, S.J.; Gustafson, R.G.; Lutz, R.A. Cryptic species of deep-sea clams (Mollusca: Bivalvia: Vesicomyidae) from hydrothermal vent and cold-water seep environments. Deep-Sea Res. Part I 1994, 41, 1171-1189. [CrossRef]

37. Wei, C.L.; Rowe, G.T.; Fain Hubbard, G.; Scheltema, A.H.; Wilson, G.D.F.; Petrescu, I.; Foster, J.M.; Wicksten, M.K.; Chen, M.; Davenport, R.; et al. Bathymetric zonation of deep-sea macrofauna in relation to export of surface phytoplankton production. Mar. Ecol. Prog. Ser. 2010, 399, 1-14. [CrossRef]

38. Tunnell, J.W.; Andrews, J.; Barrera, N.C.; Moretzsohn, F. Encyclopedia of Texas Seashells: Identification, Ecology, Distribution, and History; Tunnell, J.W.J., Ed.; Texas A\&M University Press: Corpus Christi, TX, USA, 2010; ISBN 9781603441414.

39. Turgeon, D.D.; Lyons, W.G.; Mikkelsen, P.; Rosenberg, G.; Moretzsohn, F. Bivalvia (Mollusca) of the Gulf of Mexico. In Gulf of Mexico. Origin, Waters and Biota; Felder, D.L., Kamp, D.K., Eds.; Texas A\&M University Press: College Station, TX, USA, 2009; pp. 711-744.

40. Hernández-Ávila, I.; Pech, D.; Ocaña, F.A.; Árcega-Cabrera, F.; Enriquez, C. Shelf and deep-water benthic macrofauna assemblages from the western Gulf of Mexico: Temporal dynamics and environmental drivers. Mar. Environ. Res. 2021, 165, 105241. [CrossRef]

41. Trudgill, B.D.; Rowan, M.G.; Fiduk, J.C.; Weimer, P.; Gale, P.E.; Korn, B.E.; Phair, R.L.; Gafford, W.T.; Roberts, G.R.; Dobbs, S.W. The Perdido Fold Belt, northwestern deep Gulf of Mexico; part 1, Structural geometry, evolution and regional implications. Am. Assoc. Pet. Geol. Bull. 1999, 83, 88-113.

42. Baguley, J.G.; Montagna, P.A.; Hyde, L.J.; Kalke, R.D.; Rowe, G.T. Metazoan meiofauna abundance in relation to environmental variables in the northern Gulf of Mexico deep sea. Deep-Sea Res. Part I 2006, 53, 1344-1362. [CrossRef]

43. Waller, T. Structural Analysis of the Perdido Fold Belt: Timing, Evolution, and Structural Style; Texas A\&M University: College Station, TX, USA, 2007.

44. Cisterna-Céliz, J.A.; Marcelino-Barros, M.; Herguera, J.C.; Rocha-Olivares, A. Metacommunity analysis of meiobenthos of deep-sea sediments from the Gulf of Mexico. Mar. Biodivers. 2019, 49, 1217-1231. [CrossRef]

45. Díaz-Asencio, M.; Bartrina, V.F.; Herguera, J.C. Sediment accumulation patterns on the slopes and abyssal plain of the southern Gulf of Mexico. Deep-Sea Res. Part I 2019, 146, 11-23. [CrossRef]

46. Dall, W.H. Reports on the results of dredging, under the supervision of Alexander Agassiz, in the Gulf of Mexico and in the Caribbean Sea (1877-78), by the United States Coast Survey Steamer "Blake", Lieutenant-Commander C.D. Sigsbee, U.S.N., and Commander J.R. Bart. Bull. Mus. Comp. Zool. 1881, 9, 33-144.

47. Abbott, R.T. American Seashells. The marine Mollusca of the Atlantic and Pacific Coast of North America; Van Nostrand Reinhold Company: New York, NY, USA, 1974; ISBN 9780442202286.

48. Mikkelsen, P.M.; Bieler, R. Seashells of Southern Florida Living Marine Mollusks of the Florida Keys and Adjacent Regions; Princeton University Press: Princeton, NJ, USA, 2008; ISBN 13:978-0-691-11606-8.

49. Redfern, C. Bahamian Seashells: 1161 Species from Abaco, Bahamas; Bahamianseashells.com, Inc.: Boca Raton, FL, USA, 2013.

50. Bouchet, P.; Rocroi, J.-P.; Bieler, R.; Carter, J.G.; Coan, E.V. Nomenclator of Bivalve Families with a Classification of Bivalve Families. Malacologia 2010, 52, 1-184. [CrossRef]

51. WoRMS World Register of Marine Species. Available online: http:/ / www.marinespecies.org (accessed on 20 June 2018).

52. Whittaker, R.H. Evolution and Measurement of Species Diversity. Taxon 1972, 21, 213-251. [CrossRef]

53. Anderson, M.J.; Ellingsen, K.E.; McArdle, B.H. Multivariate dispersion as a measure of beta diversity. Ecol. Lett. 2006, 9, 683-693. [CrossRef]

54. Gotelli, N.J.; Colwell, R.R. Estimating species richness. In Biological Diversity: Frontiers in Measurement and Assessment; Magurran, A.E., McGill, B.J., Eds.; Oxford University Press Oxford: New York, NY, USA, 2011; pp. 39-54.

55. Walther, B.A.; Moore, J.L. The concepts of bias, precision and accuracy, and their use in testing the performance of species richness estimators, with a literature review of estimator performance. Ecography 2005, 28, 815-829. [CrossRef]

56. Reese, G.C.; Wilson, K.R.; Flather, C.H. Performance of species richness estimators across assemblage types and survey parameters. Glob. Ecol. Biogeogr. 2014, 23, 585-594. [CrossRef]

57. Anderson, M.J.; Crist, T.O.; Chase, J.M.; Vellend, M.; Inouye, B.D.; Freestone, A.L.; Sanders, N.J.; Cornell, H.V.; Comita, L.S.; Davies, K.F.; et al. Navigating the multiple meanings of $\beta$ diversity: A roadmap for the practicing ecologist. Ecol. Lett. 2011, 14, 19-28. [CrossRef]

58. Baselga, A. Partitioning the turnover and nestedness components of beta diversity. Glob. Ecol. Biogeogr. 2010, 19, 134-143. [CrossRef]

59. Quinn, G.P.; Keough, M.J. Experimental Design and Data Analysis for Biologists; Cambridge University Press: New York, NY, USA, 2002; ISBN 9780521811286.

60. Anderson, M.J. Permutation tests for univariate or multivariate analysis of variance and regression. Can. J. Fish. Aquat. Sci. 2011, 58, 626-639. [CrossRef]

61. Anderson, M.J. Permutational Multivariate Analysis of Variance (PERMANOVA). In Wiley StatsRef: Statistics Reference Online; John Wiley \& Sons, Ltd.: Hoboken, NJ, USA, 2017; pp. 1-15.

62. Clarke, K.R.; Tweedley, J.R.; Valesini, F.J. Simple shade plots aid better long-term choices of data pre-treatment in multivariate assemblage studies. J. Mar. Biol. Assoc. UK 2014, 94, 1-16. [CrossRef]

63. Legendre, P.; Legendre, L. Numerical Ecology, 3rd ed.; Elsevier Science: Amsterdam, The Netherlands, 2012. 
64. R Development Core Team R: A Language and Environment for Statistical Computing; R Foundation for Statistical Computing: Vienna, Austria, 2013.

65. Oksanen, J.; Guillaume Blanchet, F.; Friendly, M.; Kindt, R.; Legendre, P.; McGlinn, D.; Minchin, P.R.; O’Hara, R.B.; Simpson, G.L.; Solymos, P.; et al. Vegan: Community Ecology Package; R Package Version 2.3-0; R Foundation for Statistical Computing: Vienna, Austria, 2015.

66. Baselga, A.; Orme, C.D.L. Betapart: An R package for the study of beta diversity. Methods Ecol. Evol. 2012, 3, 808-812. [CrossRef]

67. Correa-Sandoval, A.; Rodríguez-Castro, J.H. Zoogeografía de los bivalvos marinos de la costa de Tamaulipas, México. Rev. Biol. Mar. Oceanogr. 2013, 48, 565-584. [CrossRef]

68. García-Cubas, A. Ecología y Distribución de los Micromoluscos Recientes de la LAGUNA Madre, Tamaulipas, México; Universidad Nacional Autonoma de México, Instituto de Geología: Mexico City, Mexico, 1968.

69. Secretaria de Marina. Fauna Malacológica del Área Costera de Tampico a Matamoros, Tamaulipas, México; Dirección General de Oceanografía: Ciudad de México, Mexico, 1980.

70. Rice, W.H.; Kornicker, S. Mollusks of Alacran Reef, Campeche Bank, México. Publ. Inst. Mar. Sci. 1962, 8, $366-403$.

71. Washburn, T.; Rhodes, A.C.E.; Montagna, P.A. Benthic taxa as potential indicators of a deep-sea oil spill. Ecol. Indic. 2016, 71, 587-597. [CrossRef]

72. Sabelli, B.; Taviani, M. The making of the Mediterranean Molluscan biodiversity. In The Mediterranean Sea: Its History and Present Challenges; Springer: Dordrecht, The Netherlands, 2014; Volume 9789400767, pp. 285-306, ISBN 9789400767041.

73. Coan, E.V.; Valentich-Scott, P.; Sadeghian, P.S. Bivalve Seashells of Tropical West America. Marine Bivalve Mollusks from Baja California to Northern Peru. Museum of Natural History: Santa Barbara, CA, USA, 2012.

74. Keen, A.M. Seashells of Tropical West America: Marine Mollusks from Baja California to Peru. Stanford University: Stanford, CA, USA, 1971.

75. Rex, M.A. Deep-Sea Species Diversity: Decreased Gastropod Diversity at Abyssal Depths. Science 1973, 181, 1051-1053. [CrossRef]

76. Escobar-Briones, E.; García-Villalobos, F.J. Distribution of total organic carbon and total nitrogen in deep-sea sediments from the southwestern Gulf of Mexico. Bol. Soc. Geol. Mex. 2009, 61, 73-86. [CrossRef]

77. Brault, S.; Stuart, C.T.; Wagstaff, M.C.; McClain, C.R.; Allen, J.A.; Rex, M.A. Contrasting patterns of $\alpha$ - and B-diversity in deep-sea bivalves of the eastern and western North Atlantic. Deep-Sea Res. Part II 2013, 92, 157-164. [CrossRef]

78. McClain, C.R.; Lundsten, L.; Barry, J.; DeVogelaere, A. Assemblage structure, but not diversity or density, change with depth on a northeast Pacific seamount. Mar. Ecol. 2010, 31, 14-25. [CrossRef]

79. Cartes, J.E.; Jaume, D.; Madurell, T. Local changes in the composition and community structure of suprabenthic peracarid crustaceans on the bathyal Mediterranean: Influence of environmental factors. Mar. Biol. 2003, 143, 745-758. [CrossRef]

80. Cartes, J.E.; Carrassón, M. Influence of trophic variables on the depth-range distributions and zonation rates of deep-sea megafauna: The case of the Western Mediterranean assemblages. Deep-Sea Res. Part I 2004, 51, 263-279. [CrossRef]

81. McClain, C.R.; Rex, M.A. Toward a Conceptual Understanding of $\beta$-Diversity in the Deep-Sea Benthos. Annu. Rev. Ecol. Evol. Syst. 2015, 46, 623-642. [CrossRef] 